\title{
GABA-ergic Cell Therapy for Epilepsy: Advances, Limitations and Challenges
}

\section{Ashok K. Shetty and Dinesh Upadhya}

Institute for Regenerative Medicine, Texas A\&M Health Science Center College of Medicine, Temple, Texas

Research Service, Olin E. Teague Veterans' Medical Center, Central Texas Veterans Health Care System, Temple, Texas

Department of Molecular and Cellular Medicine, Texas A\&M Health Science Center College of Medicine, College Station, Texas

Number of Tables: 3

Number of Figures: 2

Key words: Epilepsy; GABA-ergic interneurons; Lateral ganglionic eminence; Medial ganglionic eminence; Neural cell grafts; Pain; Schizophrenia; Stem cell therapy; Temporal lobe epilepsy

Address for Correspondence:

Ashok K. Shetty, Ph.D.

Professor and Director of Neurosciences

Institute for Regenerative Medicine

Texas A\&M Health Science Center College of Medicine

5701 Airport Road, Module C

Temple, Texas 76502

Phone: 254-771-6804

E-mail: shetty@medicine.tamhsc.edu 


\begin{abstract}
Diminution in the number of gamma-amino butyric acid positive (GABA-ergic) interneurons and their axon terminals, and/or alterations in functional inhibition are conspicuous brain alterations believed to contribute to the persistence of seizures in acquired epilepsies such as temporal lobe epilepsy. This has steered a perception that replacement of lost GABA-ergic interneurons would improve inhibitory synaptic neurotransmission in the epileptic brain region and thereby reduce the occurrence of seizures. Indeed, studies using animal prototypes have reported that grafting of GABA-ergic progenitors derived from multiple sources into epileptic regions can reduce seizures. This review deliberates recent advances, limitations and challenges concerning the development of GABA-ergic cell therapy for epilepsy. The efficacy and limitations of grafts of primary GABA-ergic progenitors from the embryonic lateral ganglionic eminence and medial ganglionic eminence (MGE), neural stem/progenitor cells expanded from MGE, and MGE-like progenitors generated from human pluripotent stem cells for alleviating seizures and co-morbidities of epilepsy are conferred. Additional studies required for possible clinical application of GABA-ergic cell therapy for epilepsy are also summarized.
\end{abstract}




\section{CONTENTS}

1. Introduction

2. Efficacy of Primary gamma-amino butyric acid positive (GABA-ergic) Cell Grafts for Mediating Anti-seizure Effects

2.1. Competence of lateral ganglionic eminence (LGE) progenitors

2.2. Capability of medial ganglionic eminence (MGE) progenitors

2.2.1. Efficiency when utilized as prophylactic treatment

2.2.2. Proficiency when grafted after the emergence of SRS

3. Effectiveness of Stem/Progenitor Cells Generating GABA-ergic Interneurons

3.1. Ability of NSCs derived from rat MGE and human embryonic telencephalon

3.2. Competence of MGE-like cells from embryonic stem cells (ESCS) and induced pluripotent stem cells (iPSCs)

4. Required Additional Studies for Clinical Application of GABA-ergic Cell Grafting

4.1. Grafting studies in prototypes that simulate drug-resistant epilepsy

4.2. Analyses of long-term effects of grafting

4.3. Usefulness of grafts for reversing learning, memory and mood impairments

4.4. Generation apt human GABA-ergic donor cells for clinical application

5. Conclusions 


\section{Introduction}

Epilepsy affects $\sim 60$ million people in the world and 1\% Americans (Jobst and Cascino, 2015). Approximately $30 \%$ of epileptic patients have temporal lobe epilepsy (TLE) typified by progressive development of complex partial seizures, hippocampal neurodegeneration and comorbidities such as cognitive and mood impairments (Devinsky, 2004; Lewis, 2005). While antiepileptic drugs (AEDs) have been valuable for seizure control in most patients, $-30-40 \%$ of patients typically develop pharmacoresistant or intractable epilepsy, defined as failure of two AEDs given at apt doses (Kwan et al., 2010). Furthermore, as AEDs merely suppress seizures without modifying the disease, co-morbidities of epilepsy such as cognitive and mood dysfunction may persist even in patients with complete seizure control (Stafstrom, 2014). Alternative therapeutic strategies such as resection of the epileptic brain tissue and surrounding regions, ketogenic diet, deep brain or vagus nerve stimulation are not suitable for all patients due to either only moderate efficiency or undesirable side effects (DeGiorgio et al., 2000; Wiebe et al., 2001; Andrade et al., 2006; Kossoff et al., 2008; Cukiert et al., 2010). In view of these issues, a significant focus is now directed towards development of alternative approaches that have the potential to modify the disease process. Cell transplantation is one of the strategies currently being examined rigorously in preclinical models of epilepsy. These studies include testing the effects of early grafting intervention following brain injury or status epilepticus (SE) on curbing the development of chronic epilepsy and co-morbidities as well as studies examining the effects of grafts placed into the chronically epileptic foci for enduring suppression of well established spontaneous recurrent seizures (SRS) and reversing cognitive and mood impairments (Shetty and Hattiangady, 2007a; Shetty, 2011; Shetty, 2014).

A variety of cells have been tested in preclinical models of epilepsy for their proficiency to suppress seizures following grafting into distinct regions of the brain. The donor cells examined with intracerebral grafting include hippocampal precursor cells, neural stem cells (NSCs), primary gamma-amino butyric acid positive (GABA-ergic) cells or GABA-ergic precursor cells from both the embryonic lateral ganglionic eminence (LGE) and the medial ganglionic eminence (MGE), GABAergic progenitors derived from the mouse and human embryonic stem cells (mESCs and hESCs) and human induced pluripotent stem cells (hiPSCs). The donor cells tested with systemic administration are mainly comprised of bone marrow derived mononuclear cells and mesenchymal stem cells. Although the principal objective with all types of donor cells is to alleviate the frequency and severity of SRS and related co-morbidities, the mechanisms by which diverse types of donor 
cells mediate these beneficial effects diverge greatly. While the goal of hippocampal precursor cell grafting in TLE prototypes is to reconstruct the disrupted circuitry and thereby reduce the extent of aberrant mossy fiber sprouting as well as activate the existing dormant host GABA-ergic interneurons (Hattiangady et al., 2006; Rao et al., 2007; Shetty and Turner, 1997a, b; Shetty et al., 2000, 2005; Shetty and Hattiangady, 2007b), the aim of NSC grafting is to modify the disease through introduction of both new GABA-ergic interneurons and new astrocytes secreting a multitude of beneficial neurotrophic factors including anticonvulsant proteins such as glial cell-line derived neurotrophic factor (GDNF) (Lee et al., 2014; Shetty, 2014; Waldau et al., 2010). In contrast, the purpose of GABA-ergic cell therapy is to replace lost GABA-ergic interneurons and thereby improve the inhibitory synaptic neurotransmission in the epileptic area of the brain (Hattiangady et al., 2008; Hunt et al., 2013; Cunningham et al., 2014; Henderson et al., 2014). On the other hand, the primary objective of systemic administration of bone marrow derived mononuclear cells and/or mesenchymal stem cells is to modulate the immune system to curtail the extent of chronic inflammation in the epileptic brain regions (Agadi and Shetty, 2015). Interestingly, all of these approaches have reduced the frequency and intensity of SRS in pre-clinical models of TLE and some have also produced positive effects on cognitive function. Thus, several distinct donor cell types can modulate the plasticity of the hippocampus, modify epileptogenesis, reduce the occurrences of SRS and alleviate cognitive dysfunction, though the extent of beneficial effects varied depending upon the animal model employed, the timing of grafting intervention after the commencement of epilepsy, and the time-point of measurement of SRS after grafting.

The aim of this review is to deliberate recent advances, limitations and challenges pertaining to the development of GABA-ergic cell therapy for epilepsy. Both efficacy and limitations of primary LGE and MGE cells, NSCs expanded in vitro from the embryonic MGE, and MGE-like progenitors generated from mESCs, hESCs and hiPSCs for alleviating seizures and epilepsy comorbidities in preclinical models are conferred. Additionally, studies that are required to pave the way for possible clinical application of GABA-ergic progenitors are proposed.

\section{Efficacy of Primary GABA-ergic Cell Grafts for Mediating Anti-Seizure Effects}

A multitude of cellular and molecular changes enhance excitatory neurotransmission in the epileptic hippocampus. Among these, reduced numbers of GABA-ergic interneurons (Kobayashi and Buckmaster, 2003; Sloviter et al., 2003; Ben-Ari, 2006; Shetty et al., 2009; Kuruba et al., 2011), loss of functional inhibition (Lloyd et al., 1986; Cornish and Wheal, 1989; During et al., 
1995) and diminished numbers of GABA-ergic terminals (Esclapez and Trottier, 1989) are conspicuous alterations believed to contribute to the persistence of SRS. This evidence has guided a straightforward concept that grafting of cells that release the inhibitory neurotransmitter GABA into the seizure focus would greatly restrain SRS (Loscher et al., 2008). Indeed, grafting of GABAsoaked beads, immortalized GABA-ergic cells, cells engineered to produce GABA or fetal GABAergic cells into the epileptic foci produces anticonvulsant effects in a variety of animal models (Kokaia et al., 1994; Loscher et al., 1998; Gernert et al., 2002; Thompson, 2005; Castillo et al., 2006, 2008; Nolte et al., 2008; Handreck et al., 2014). However, anti-seizure effects were either modest or transient in most of these studies, presumably because of poor graft cell survival. Subsequent studies, by utilizing diverse rodent models of epilepsy have ascertained the effects of progenitor cells from the embryonic rat LGE and mouse or rat MGE (Table 1). The following sections deliberate on the capability of these donor cell types for: suppressing SRS, easing behavioral co-morbidities of epilepsy, GABA-ergic interneuron differentiation, long-term survival in the epileptic brain region, and preventing adverse synaptic alterations in the host brain.

\subsection{Competence of LGE progenitors}

Hattiangady and colleagues examined the long-term effects of grafting embryonic day 15 (E15) rat LGE progenitor cells pre-treated with fibroblast growth factor-2 (FGF-2) and a caspase inhibitor into the hippocampus 4-days after kainate-induced SE in adult rats (Hattiangady et al., 2008, Table 1). Measurement of SRS at 9-12 months after grafting revealed that, animals receiving LGE progenitor cell grafting after SE displayed 67-89\% fewer SRS than animals receiving shamgrafting surgery or no grafts after SE. At 12 months post-grafting, the average frequency of SRS was $<0.60 /$ hour in epileptic animals receiving LGE progenitor cells, in contrast to $>3.0$ seizures/hour observed in epileptic animals receiving sham-grafting surgery and "epilepsy-only" control animals. Graft cell survival at one-year post-grafting was $\sim 33 \%$ of injected cells, and $\sim 69 \%$ of surviving cells differentiated into GABA-ergic neurons comprising subclasses expressing neuropeptide $\mathrm{Y}$ (NPY), parvalbumin (PV), calbindin (CBN) and calretinin (CR). Extrapolation of numbers of graft-derived cells survived and the percentage of GABA-ergic neurons among graftderived cells suggested that $\sim 67,000$ new GABA-ergic neurons derived from LGE progenitor cell grafts persisted in each hippocampus until a year in this study. Furthermore, the loss of hippocampal calbindin in DG granule cells, a conspicuous alteration typically seen in the hippocampus of chronically epileptic animals (Magloczky et al., 1997; Nagerl et al., 2000; Shetty and Hattiangady, 2007b) was considerably attenuated in animals receiving grafts. However, mossy 
fiber sprouting into the dentate supragranular layer (DSGL), a likely epileptogenic change contributing to the occurrence or extent of SRS (Cronin and Dudek, 1988; Wuarin and Dudek, 2001; Shetty et al., 2005; Buckmaster, 2014), remained comparable between animals receiving grafts and epilepsy-alone controls. This study thus provided the first evidence that grafting of appropriately treated embryonic LGE cells into hippocampi after SE is efficacious for a lasting suppression of the frequency of SRS in the chronic epilepsy period. Survival of large numbers of graft-derived GABA-ergic neurons belonging to several subclasses of interneurons and no effects of grafting on aberrant mossy fiber sprouting observed a year after transplantation further suggested that strengthening of the inhibitory control in the host hippocampus mediated enduring beneficial effect of grafts on SRS. Additionally, this study pointed out that even heterotopic grafting of GABA-ergic progenitors into the epileptic area could mediate anti-seizure effects because LGE progenitors used as donor cells in this study mostly form olfactory bulb interneurons in the developing brain (Wichterle et al., 1999; Southwell et al., 2014).

\subsection{Capability of MGE progenitors}

The MGEs of the ventral telencephalon in the developing brain generate diverse subpopulations of interneuron progenitors. These cells then display long-distance tangential migration to reach the cerebral cortex and other forebrain regions where they differentiate finally into distinct subclasses of mature interneurons (Southwell et al., 2014). MGE progenitors are considered attractive as a source of GABA-ergic progenitors for grafting in preclinical models of epilepsy due to their competence to spread or migrate extensively to the surrounding brain regions from the grafted site. Moreover, MGE progenitors can generate interneuron subpopulations typically formed by them during development even when grafted into distinct heterotopic regions of the adult brain (Wichterle et al., 1999; Alvarez-Dolado et al., 2006; Southwell et al., 2010; Southwell et al., 2014).

\subsubsection{Efficiency when utilized as prophylactic treatment}

Initial investigations on the efficacy of MGE progenitor cells for easing seizures were mostly prophylactic studies. These involved grafting of MGE progenitors into the cerebral cortex, the hippocampus or amygdala before the emergence or induction of seizures in distinct mouse models and in a rat model of kindling epilepsy. Baraban and associates examined the prophylactic effect of grafting MGE progenitors from E13.5 mouse into the cerebral cortex of postnatal day 2 mutant 
mice lacking a shaker-like potassium channel (Kv1.1./Kcna1) mimicking a neuronal ion channelopathy associated with epilepsy in humans (Baraban et al., 2009, Table 1).

Electroencephalographic (EEG) recordings in the 2nd month after grafting revealed significant reductions in both frequency and duration of spontaneous EEG seizures, as compared to mutant mice receiving vehicle or dead cell grafts. While the percentage of graft cell survival is unknown, differentiation assays revealed $\sim 65 \%$ of GABA-ergic neurons among graft-derived cells comprising subclasses of interneurons expressing NPY, PV, CBN and CR. In a subsequent study, E12.5 mouse MGE cells were grafted into the hippocampus of mice a week after the elimination of subclasses of GABA-ergic interneurons via an injection of SSP-Sap and seizure susceptibility was measured using pentylenetetrazol (PTZ) injections 2-months post-grafting (Zipancic et al., 2010, Table 1). The chemical SSP-Sap is a conjugate of peptidase-resistant $\left[\operatorname{Sar}^{9}, \operatorname{Met}\left(\mathrm{O}_{2}\right)^{11}\right]$ analog of substance $P$ and the ribosome-inactivating protein saporin, which specifically eliminates cells expressing substance $P$ (neurokinin-1, NK-1) receptor. The results demonstrated decreased sensitivity and diminished mortality to PTZ induced seizures in animals receiving intrahippocampal MGE cell grafts, in comparison to non-grafted animals. The survival of grafted MGE cells was $\sim 20 \%$ and among surviving grafted cells $\sim 65 \%$ expressed GABA, which also comprised subclasses expressing NPY PV, CR, somatostatin (SOM) and NK-1. Importantly, reduced frequencies of inhibitory postsynaptic currents in CA1 pyramidal neurons caused by GABA-ergic interneuron ablation were restored to normal levels in hippocampi receiving MGE cell grafts. Calcagnotto and associates, using a maximum electroconvulsive shock model, also demonstrated increased seizure thresholds, reduced seizure severity and lower seizure-related mortality in adult mice that received mouse MGE progenitor cell grafts into their cortices in the neonatal period, in comparison to non-grafted animals (Calcagnotto et al., 2010, Table 1).

A study in a rat model of kindling epilepsy also showed the efficiency of rat MGE cells for reducing seizures (Gallego et al., 2010, Table 1). Grafting E14.5 rat MGE into the amygdala following 3 days of full kindling increased thresholds for after discharges and seizures at 3-24 days post-grafting, in comparison to kindled rats receiving fibroblasts. This positive effect was associated with the occurrence of GABA+ neurons among surviving grafted cells. In another study mouse MGE progenitors were grafted into adult mouse sensorimotor cortex and then 4aminopyridine (4-AP) was injected into the cortex $\sim 2 \mathrm{~mm}$ away from the site of grafts at 2-8 weeks post-grafting (De la Cruz et al., 2011, Table 1). Measurement of 4-AP induced acute focal ictal epileptiform discharges revealed a dramatic decrease in local field potential power at the MGE transplanted site, even when graft-derived interneurons were present in low densities. Thus, a 
series of prophylactic studies initially showed the promise of MGE progenitor cell grafts for treating epilepsy but did not specifically examine whether MGE progenitor cell grafting performed after the emergence of epilepsy would be efficacious for suppressing SRS.

\subsubsection{Proficiency when grafted after the emergence of SRS}

Several studies have now examined the capability of MGE cell grafts for alleviating SRS in mouse and rat models of TLE. Hunt and associates investigated the effects of E13.5 mouse MGE progenitors grafted bilaterally into the hippocampus or amygdala of adult mice $\sim 20$ days after pilocarpine induced SE (i.e. after the occurrence of first SRS) (Hunt et al., 2013, Table 2). Continuous EEG recordings for 7-10 days in the 3rd month after grafting demonstrated an impressive 92\% reduction in the frequency of SRS in animals that received grafts into the hippocampi but not the amygdala, in comparison to epilepsy-only controls. The mean seizure frequency was $0.17 /$ day in grafted epileptic animals, in comparison to over 2.0 seizures/day in vehicle-injected epileptic animals. Furthermore, grafting improved short-term memory retention when examined through a probe test conducted an hour after the last training session in a water maze test. Grafting also promoted alleviation of hyperactivity in epileptic animals. Precise percentages of surviving grafted cells or fractions of graft-derived cells that differentiated into diverse subclasses of interneurons were not reported for the epileptic mice. However, a parallel MGE cell grafting experiment in normal adult mice revealed 33\% survival at 7 days post-grafting, $15 \%$ survival at 30 days post-grafting and differentiation of graft-derived cells into diverse subclasses of interneurons exhibiting fast-spiking, regular spiking, late-spiking and burst spiking electrophysiological properties (Hunt et al., 2013). Characterization through dual immunofluorescence methods also revealed the presence of subclasses of interneurons expressing distinct calcium binding proteins and neuropeptides among graft-derived cells. Additionally, grafting did not affect the extent of aberrant mossy fiber sprouting in the DSGL (a substrate believed to contribute to the occurrence and/or severity of SRS) of epileptic mice, supporting that a dramatic seizure-suppression seen following MGE cell grafting is likely mediated through an enhanced inhibitory synaptic transmission in the epileptic hippocampus.

Another recent study performed continuous video-EEG recordings for extended periods (50-60 days) after bilateral grafting of E13.5 mouse MGE cells into the DG of adult mice at $\sim 2$ weeks after pilocarpine induced SE (i.e. after the occurrence of first SRS, Henderson et al., 2014, Table 2). Such long-term analysis revealed an overall 35\% decrease in the frequency of SRS 
associated with reductions in seizure duration and severity in grafted epileptic animals, in comparison to epileptic animals receiving media injections into the DG. The percentage survival of grafted cells was not reported but graft-derived cells differentiated into interneurons expressing PV, CBN, SOM and NPY in the hippocampus of epileptic mice. Moreover, morphological and electrophysiological analyses demonstrated that axons from grafted inhibitory neurons traversed layers of the DG and established functional inhibitory synaptic contacts on the soma, dendrites and axons of host granule cells. As observed in previous studies (Hattiangady et al., 2008; Hunt et al., 2013) grafting of GABA-ergic progenitors did not affect the extent of aberrant mossy fiber sprouting occurring in the DSGL, reinforcing the concept that seizure-suppression in epileptic mice receiving GABA-ergic cell grafts is due to an enhanced inhibitory synaptic transmission. In addition to demonstrating multiple beneficial effects, this study uncovered that seizure-suppressing effect of grafts does not persist at an extended time-point after grafting. This was evident from a significant suppression of the frequency, duration and severity of SRS in the period corresponding to 47-67 days post-grafting, but not in periods corresponding to 26-46 days post-grafting (early period) and 81-100 days post-grafting (later period). Inability of grafts to suppress SRS in the early period likely reflects the time needed for grafted interneuron progenitors to acquire morphological and physiological maturation in the epileptic brain. While the precise reason for failure of grafts to suppress SRS in the later period after grafting (after showing effectiveness in the immediate previous period) is yet to be identified, it may be that a progressive loss or dysfunction of graftderived GABA-ergic interneurons occurs with the evolution of disease into an advanced phase of epilepsy.

An investigation in a rat model of chronic TLE showed that bilateral grafting of E14 rat MGE progenitors into the hippocampus alleviates seizures and improves cognitive and memory function (Shetty et al., 2014, Table 2). In this study, two cohorts of animals that displayed comparable SRS at 3-4 months after kainic acid induced SE were chosen. One of the cohorts received grafts and the other cohort was maintained as "epilepsy-only" controls. Measurement of seizures two months afterwards revealed that grafting reduced the frequency and duration of SRS in epileptic animals by $91-93 \%$, in comparison to their pre-grafting seizure scores. This was also associated with complete elimination of stage $\mathrm{V}$ seizures. In comparison to age-matched "epilepsy-only" controls, animals receiving grafts displayed $\sim 87 \%$ reduction in the frequency of all EEG-SRS, $\sim 97 \%$ reduction in the frequency of EEG-SRS with behavioral changes (such as unilateral forelimb clonus, bilateral forelimb clonus with or without rearing and falling) and 59\% reduction in the duration of individual seizures. The frequency of seizures was $\sim 0.1 /$ hour in grafted epileptic 
animals, in comparison to $>0.6$ seizures/hour in "epilepsy-only" controls. Grafted animals also displayed improved spatial learning and memory function in a water maze test (Shetty et al., 2014, Table 2). Nearly $30 \%$ of grafted cells survived and most of which ( $91 \%)$ differentiated into GABAergic interneurons expressing markers such as NPY, SOM, PV, CBN, CR and reelin, when quantified $\sim 3$ months after grafting. The overall migration of graft-derived cells was modest with cells migrating mostly into the immediate surrounding regions of the graft core. Thus, MGE cell grafting is efficacious for easing seizures and cognitive and memory dysfunction in a rat model of TLE too. However, the permanence of these beneficial effects of grafts remains to be investigated through analyses at extended time-points after grafting. Furthermore, Hammad and colleagues have examined the usefulness of MGE cell grafting in an animal model of absence epilepsy (AE) (Hammad et al., 2014, Table 2). By grafting E12.5 mouse MGE cells into the occipital cortex of stargazer mouse (a prototype exhibiting absence seizures), this study showed that MGE cell grafting can reduce absence seizures. The overall reductions were 53-89\% at $~ 1-4$ months after grafting, in comparison to stargazer animal groups receiving dead cell grafts, vehicle or no grafts. The frequency of absence seizures (based on head tilts) was reduced to $<40 /$ hour in grafted animals, in comparison to $>90 /$ hour in animals receiving no grafts. The percentage survival of graftderived cells was not measured in this study but counts per unit volume suggested only moderate survival of grafted cells. Notably, surviving grafted cells differentiated mostly into GABA-ergic neurons (93\%). Grafting also normalized c-fos activity and network activity to an excitability challenge, providing an indirect evidence of their integration with the host circuitry. Another interesting aspect of this study is that grafting improved the lifespan of stargazer mice.

Taken together, multiple studies support that grafting primary GABA-ergic progenitors obtained from both LGE and MGE are efficacious for: (i) easing SRS in rat and mouse models of TLE, shaker-like potassium channel mutant mouse and a mouse model of seizure susceptibility; (ii) increasing seizure thresholds for after discharges and seizures in a rat prototype of kindling; and (iii) alleviating absence seizures in a mouse model of absence epilepsy. Some of these studies have also shown adequate evidence for integration of graft-derived GABA-ergic interneurons with the host circuitry and/or increased inhibitory synaptic transmission in the epileptic brain regions following grafting of GABA-ergic interneurons. 


\section{Effectiveness of Stem/Progenitor Cell Grafts Generating GABA-ergic Interneurons}

Several studies have examined the effects of grafting stem/progenitor cells that generate GABA-ergic interneurons for suppressing SRS and/or integration in animal models of TLE. The donor cells include neural stem/progenitor cells expanded from the rat MGE, and MGE-like cells derived from the mESCS, hESCs and hiPSCs.

\subsection{Ability of NSCs derived from rat MGE and human telencephalon}

Waldau and colleagues grafted NSCs expanded from E14 rat MGE into rats exhibiting chronic SRS (Waldau et al., 2010, Table 3). To simulate the microenvironment present in the hippocampus of people afflicted with pharmacoresistant TLE, grafting was performed 9-12 months after SE. Furthermore, as differences in the frequency of SRS are typical between animals in chronically epileptic groups, this study chose a group of age-matched rats displaying comparable frequency and severity of SRS and learning and memory impairments from a larger pool of rats that were chronically epileptic for prolonged periods. This selection ensured that animals' chosen for grafting experienced SRS for prolonged periods and developed learning and memory impairments before receiving grafting into their hippocampi. Quantification of behavioral SRS at 1-3 months post-grafting revealed reductions in the frequency of all SRS by $43 \%$, duration of individual SRS by $51 \%$, frequency of stage-V SRS (the most severe form of SRS in animal models of TLE) by $90 \%$ and overall time spent in seizure activity by $74 \%$. However, sham-grafting surgery did not alter the seizure frequency or the seizure duration in chronically epileptic rats. Analyses of grafted hippocampi revealed dispersion of graft-derived cells into different layers and a graft yield equivalent to $28 \%$ of injected cells. Further analyses revealed addition of $\sim 8,000$ new GABA-ergic neurons, $\sim 46,000$ new astrocytes, $\sim 2,000$ new oligodendrocyte progenitors, and $\sim 40,000$ new GDNF+ astrocytes into each hippocampus of chronically epileptic rats. Moreover, this study provided new evidence that NSC grafting triggered synthesis of GDNF (an anticonvulsant protein) in host astrocytes. This is an important plasticity induced by NSC grafts, as chronic TLE causes the loss of GDNF and other alterations in most hippocampal astrocytes. Thus, multiple mechanisms such as the addition of GABA-ergic interneurons and GDNF-releasing astrocytes, and induction of GDNF expression in the host hippocampal astrocytes likely underlie the anticonvulsant effects of grafting in this study. One issue that emerged from this study is that NSC grafting into the hippocampus of animals exhibiting TLE for prolonged periods does not improve learning and memory function and neurogenesis despite having significant seizure-suppressing effects. 
Grafting of NSCs expanded from the human telencephalon (of aborted fetuses at 13 weeks of gestation) into the epileptic hippocampus of fully kindled rats or pilocarpine-treated rats at $\sim 3$ weeks post-SE (Lee et al., 2014, Table 3) also reduced seizures, in comparison to kindled or epileptic animals receiving vehicle injections. Human NSC grafting reduced the duration of behavioral seizures and after discharges in the kindling model and reduced the frequency and duration of SRS in the pilocarpine model but had no effects on spatial learning or memory deficits. The mean seizure frequency was 0.12/day in grafted epileptic animals at 3 months post-grafting, in comparison to 0.61 seizures/day in vehicle-injected epileptic animals. Approximately $24 \%$ of graftderived cells differentiated into GABA-ergic interneurons in this study (Lee et al., 2014). Yet, NSCs from all sources do not appear to generate GABA-ergic interneurons when grafted into the epileptic hippocampus. For example, a study by Raedt and colleagues showed that NSCs expanded from the adult subventricular zone survive poorly and generate predominantly astrocytes following grafting into the sclerotic hippocampus (Raedt et al., 2009). Considering this, NSCs that show propensity for differentiating into both GABA-ergic neurons and astrocytes may be the most ideal types for seizure suppression. It remains to be investigated however whether grafting of astrocytes alone into the hippocampus is sufficient to promote suppression of SRS in chronically epileptic animals.

\subsection{Competence of MGE-like progenitors from ESCs and iPSCs}

A few recent studies have also examined the integration and efficacy of cells derived from mESCs or hESCs in animal models of TLE. One of these studies grafted mESC-derived neural progenitors into the hippocampus of epileptic mice two weeks after the induction of SE (i.e. after the occurrence of first SRS) (Maisano et al., 2012, Table 3). While the effects of grafting on SRS was not measured, morphological and electrophysiological analyses revealed that graft-derived cells differentiated into GABA-ergic interneurons and displayed electrophysiological properties of typical interneurons in the hilus of DG. This study mainly showed the promise of ESC-derived GABA-ergic interneurons for integration into the circuitry of the epileptic hippocampus. A recent study has however taken this promise to a much higher level (Cunningham et al., 2014, Table 3). In this study, MGE-like progenitors were expanded from hESCs and grafted into the hippocampus of epileptic mice -3 weeks after SE (i.e. after the occurrence of SRS). Examination of the effects at 3 months after grafting revealed an impressive 93\% reduction in the overall frequency of SRS, in comparison to epileptic mice receiving vehicle injections. The mean seizure frequency was 
0.13/day in grafted epileptic animals and 1.92/day in vehicle-injected epileptic animals. Survival of graft-derived cells was equivalent to $19 \%$ of injected cells and most graft-derived cells expressed GABA. Furthermore, extensive morphological and electrophysiological analyses demonstrated that GABA-ergic interneurons derived from grafts displayed pre-synaptic machinery for releasing GABA, properties for inhibiting host hippocampal neurons, and post-synaptic machinery for receiving excitatory inputs from hippocampal neurons. This study also demonstrated that grafting did not have any effect on the aberrant mossy fiber sprouting in the DSGL, which supported the purported mechanism of improved inhibitory synaptic transmission by GABA-ergic interneurons derived from MGE progenitor cell grafts in the chronically epileptic hippocampus. Moreover, behavioral analyses revealed that epileptic mice receiving grafts displayed alleviation of hyperactivity when measured through a photobeam activity system and aggressive behavior when evaluated semi-quantitatively via a handling test. Additionally, these animals exhibited improved short-term working memory in a Y-maze test and normal object recognition memory in a novel object recognition test.

Interestingly, 56\% of animals receiving MGE progenitors did not display any seizures during continuous EEG recordings performed for 5-10 days in the above study, suggesting a complete cure of epilepsy in some animals. However, these results require confirmation in future studies through long-term EEG recordings because mice typically display seizures in clusters and chronically epileptic mice receiving no treatment can also exhibit seizure free periods (Henderson et al., 2014). Another preliminary study examining the effects of grafting MGE-like progenitors derived from hiPSCs into the hippocampus of chronically epileptic rats showed $\sim 33-38 \%$ reductions in the frequency and duration of SRS and improvements in place recognition memory at 3-6 weeks post-grafting (Hattiangady et al., 2013).

In summary, studies support that grafting of NSCs from the embryonic MGE, GABA-ergic progenitors from the mouse ESCs and MGE-like progenitors from the ESCs and hiPSCs are efficacious for easing SRS in rat and mouse models of TLE. Studies using ESC derived GABAergic progenitors in addition demonstrated adequate evidence for integration of graft-derived GABA-ergic interneurons with the host circuitry and/or increased inhibitory synaptic transmission in the epileptic brain regions. Figure 1 illustrates the proposed migration and integration of MGEderived GABA-ergic neurons following grafting into the epileptic hippocampus. Based on multiple studies in our laboratory, it is apparent that placement of grafts at the end of hippocampal fissure results in minimal damage to cell layers of the hippocampus and facilitates migration of graft- 
derived neurons into the dentate hilus, dentate granule cell layer and CA1 and CA3 subfields. It is proposed that grafted neurons receive glutamatergic afferents from all three classes of host principal neurons: dentate granule cells, CA3 pyramidal neurons and CA1 pyramidal neurons. It is further hypothesized that axons from grafted GABA-ergic neurons make inhibitory synaptic contacts on soma and dendrites of dentate granule cells and CA1 and CA3 pyramidal neurons (Fig. 1). Indeed, Cunningham and colleagues have demonstrated the establishment of functional synaptic contacts between hESC derived grafted GABA-ergic neurons and some host hippocampal neurons (Cunningham et al., 2014). Moreover, studies employing grafting intervention early after SE (i.e. within 3 weeks of SE) have also shown improved short-term memory function (Hunt et al., 2013; Cunningham et al., 2014) but a study employing grafting at protracted time-point after SE revealed lack of beneficial effects of grafting on learning and memory (Waldau et al., 2010).

\section{Required additional studies for clinical application of GABA-ergic cell grafting}

While the results obtained so far with grafting of diverse GABA-ergic donor cells are encouraging, there are several vital issues that need to be addressed before endeavoring clinical translation of GABA-ergic cell grafting for epileptic conditions.

\subsection{Grafting studies in prototypes that simulate drug-resistant epilepsy}

The efficacy of grafts placed at chronic time-points after the commencement of SRS (chronic epilepsy) needs rigorous investigation, as most GABA-ergic cell grafting studies in TLE models performed so far employed early grafting after the initial insult (i.e. at 1-3 weeks after the induction of SE). This concern needs resolution because the most likely candidates among epilepsy patients for intracerebral grafting therapy would be patients displaying drug-resistant epilepsy, as other epilepsy patients having significant seizure control with AEDs are unlikely to seek the invasive intracerebral grafting therapy. Patients exhibiting intractable epilepsy also seem to have co-morbidities such as memory and/or mood dysfunction. Therefore, detailed studies assessing the survival, integration and efficacy of grafts placed into the epileptic brain region of animals that have displayed SRS for prolonged periods of time and shown memory and/mood impairments are necessary. Such studies may uncover additional concerns such as diminished survival, differentiation and integration of grafted cells because of robust aberrant synaptic reorganization (Buckmaster, 2014; Houser, 2014), chronic inflammation (Wilcox and Vezzani, 2014; Uludag et al., 2015), and depletion of neurotrophic factors in the chronically epileptic brain 
regions (Shetty et al., 2003). Indeed, a series of previous studies using hippocampal precursor cells have shown that grafts placed early after hippocampus injury displayed excellent survival whereas grafts placed at an extended time-point exhibited greatly diminished survival (Shetty and Turner, 1995; Zaman et al., 2001; Zaman and Shetty, 2003). In such scenario, development of improvised donor cell preparation and grafting strategies that enhance the survival and integration of graft-derived interneurons in chronically epileptic brain regions is critical (Rao et al., 2006, 2007). Furthermore, efficacy of GABA-ergic cell grafting needs to be examined in post-traumatic or poststroke epilepsy models because post-traumatic epilepsy accounts for 10-20\% of epilepsy cases in the general population (Lucke-Wold et al., 2015) and post-stroke seizures are a frequent cause of remote symptomatic epilepsy in adults, especially in older age (Gilad, 2012).

\subsection{Analyses of long-term effects of grafting}

It will be important to ascertain whether the suppression of SRS observed after GABA-ergic progenitor cell grafting is transient or enduring. One of the studies in a mouse model of TLE has reported that seizure-suppressing effect of embryonic MGE progenitor cell grafts does not persist at an extended time-point (81-100 days) after grafting (Henderson et al., 2014). Although the reason for failure of grafts to contain SRS at an advanced time-point following transplantation (after showing effectiveness in the immediate previous period) was not investigated in this study, it is plausible that a gradual degeneration or dysfunction of graft-derived GABA-ergic interneurons occurs with the progression of disease into an advanced phase of epilepsy. Such phenomenon has been seen earlier for grafted dopaminergic neurons in animal models of Parkinson's disease (PD) and PD patients (Brundin and Kordower, 2012). If this presumption turns out to be true in the future studies quantifying the survival of graft-derived GABA-ergic neurons in the epileptic hippocampus at various extended time points after grafting, this obstacle needs resolution. Improvements in donor cell preparation and/or grafting strategies promoting both increased and enduring survival of graft-derived GABA-ergic neurons in the epileptic hippocampus may resolve this issue. Indeed, a previous study has shown that $28 \%$ of grafted LGE progenitor cells pre-treated with FGF-2 and a caspase inhibitor differentiate into GABA-ergic interneurons, survive for a year after grafting in the rat epileptic hippocampus and persistently suppress SRS at an extended period (9-12 months) after grafting (Hattiangady et al., 2008). 


\subsection{Usefulness of grafts for reversing learning, memory and mood impairments}

It is currently unknown whether grafting of GABA-ergic progenitors into the chronically epileptic brain region would be effective for reversing/alleviating long-term memory impairments and depression, the two major co-morbidities of TLE. Studies in mouse models using primary MGE-progenitors or MGE-like progenitors from hESCs as donor cells have showed improvements in short-term spatial or working memory with grafting interventions occurring within 3-weeks after SE (Hunt et al., 2013; Cunningham et al., 2014). However, studies in rat models of TLE using NSCs from the rat MGE or the human fetal telencephalon as donor cells have demonstrated failure to improve spatial learning and memory impairments with grafting interventions occurring at an extended time-point after SE (Waldau et al., 2010) or early ( 3 weeks) after SE (Lee et al., 2014). Lack of improvements in learning and memory function despite considerable suppression of SRS in epileptic animals receiving grafts supports the notion that learning and memory impairments (a co-morbidity) in TLE are not entirely due to incidents of SRS but influenced by multiple changes in the epileptic hippocampus such as a greatly declined neurogenesis and disruption of the hippocampal tri-synaptic pathway due to the loss of pyramidal neurons in CA1 and CA3 subfields. Indeed, neurogenesis is one of the important substrates participating in the preservation of hippocampus-dependent learning and memory function (Deng et al., 2010). Therefore, it is plausible that inability of NSC grafts to boost the greatly diminished neurogenesis in the chronically epileptic hippocampus (Hattiangady et al., 2004) contributed to their failure to induce a beneficial outcome on learning and memory function. Greatly altered behavior of endogenous NSCs to generate predominantly astrocytes (Hattiangady and Shetty, 2010) or loss of NSCs that generate new neurons (Sierra et al., 2015) may underlie the inability of NSC grafts to boost neurogenesis in the chronically epileptic hippocampus.

Additionally, the restoration of learning and memory pathways may require grafting of cells capable of replacing lost hippocampal pyramidal neurons in the CA1 and CA3 subfields and repairing the disrupted tri-synaptic hippocampal circuitry (Shetty and Turner, 2000; Shetty et al., 2005). Thus, GABA-ergic cell therapy while efficacious for reducing SRS via enhanced inhibitory neurotransmission in the epileptic hippocampus may not necessarily improve long-term memory impairment in chronic TLE. From this perspective, grafting a mixture of donor cell types into the epileptic hippocampus seems beneficial. The donor cell mixtures might include GABA-ergic progenitors and precursors of hippocampal CA1 and CA3 pyramidal neurons, GABA-ergic progenitors and NSCs or GABA-ergic progenitors, precursors of hippocampal CA1 and CA3 
pyramidal neurons and NSCs. With the advent of techniques that direct differentiation of hESCS and hiPSCs into distinct neuronal subtypes, it is likely feasible in the future to generate all required cell types from patient-specific iPSC lines. Furthermore, a combined strategy such as grafting of GABA-ergic progenitors into the hippocampus with systemic administration of compounds or drugs that alleviate chronic inflammation and/or enhance neurogenesis appears advantageous. Such approaches may considerably suppress SRS as well as alleviate long-term memory and mood impairments via increased neurogenesis.

\subsection{Generation of apt human GABA-ergic donor cells for clinical application}

The other important issue facing future studies is generation of appropriate and adequate donor GABA-ergic progenitors for clinical application of grafting. Because LGE or MGE progenitors are only found in the fetal brain of a specific age, it requires the use of fetuses as a source of these cells. However, the use of human fetal tissues has ethical issues and is also impracticable for obtaining the required amounts of cells for clinical application. Therefore, generating MGE-like progenitors from human embryonic stem cells (hESCs) and the human induced pluripotent stem cells (hiPSCs) via apt directed differentiation methods is gaining momentum. Figure 2 illustrates the sequence of steps, cell types and the time-span required for establishing patient-specific MGElike GABA-ergic cell therapy for epilepsy. In brief, the steps comprise obtaining a skin biopsy from the patient, isolation of skin fibroblasts, reprogramming fibroblasts using transcription factors such as Sox-2, Oct-4, C-Myc and Klf-4 in culture, generation of iPSC clones, expansion of iPSCs as embryoid bodies, neural induction and generation of neural rosettes, expansion of rosettes as neurospheres in a sonic hedgehog containing medium to direct the differentiation of NSCs into MGE-like progenitors expressing the transcription factor Nkx2.1 (Liu et al., 2013a,b). Once iPSC clones are established from patients, preparing the required number of cells would take about 2530 days. While several groups have been successful in obtaining MGE-like cells from hESCs and hiPSCs (Chen et al., 2013; Liu et al., 2013a, b; Maroof et al., 2013; Nicholas et al., 2013), testing their efficacy in preclinical models of epilepsy have just commenced but the initial results are encouraging (Hattiangady et al., 2013; Cunningham et al., 2014). Nonetheless, rigorous long-term studies on both safety and efficacy using these donor cells are critical because they seem to mature very slowly after grafting into the postnatal neocortex (Nicholas et al., 2013) or the adult epileptic hippocampus (Cunningham et al., 2014). Approaches that accelerate their differentiation into mature GABA-ergic interneurons after grafting are needed to obtain efficacy to desirable levels. Furthermore, because of the likelihood that cells expanded from hESCs and hiPSCs may 
carry genetic and epigenetic abnormalities (Okano et al., 2013), examining every batch of progenitors for normal neuronal (including interneuron specific) gene signatures may be required for clinical use.

Besides, it will be necessary to purify interneuron progenitors generated from hESCs and hiPSCs to one hundred percent as presence of even a solitary pluripotent stem cell in cell suspension prepared for grafting may possibly form teratoma, a mixed tumor comprising tissue types generated from ectoderm, endoderm and mesoderm lineage cells. Advanced approaches that eliminate teratoma formation from cells derived from hESCs and hiPSCs following grafting may resolve this obstacle. Pertaining to interneuron progenitors generated from hESCs and hiPSCs, adaptation of the method developed to select interneuron progenitors expressing Lhx6 (a promoter active in postmitotic interneurons derived from MGE) appears useful. This technique involves isolation of cells expressing GFP under the control of Lhx6 via fluorescence activated cell sorting (Maroof et al., 2010). Additionally, development of techniques to obtain pure populations of subclasses of interneurons (e.g. those expressing PV, SST or NPY alone) would further aid in choosing the donor cell type specifically lost in diverse epileptic conditions. There has been some progress already towards generating subtypes of interneurons from ESCs (Au et al., 2013; Tyson et al., 2015). With the advent of direct reprogramming techniques for generating specific types of neural cells, it may also be possible to generate interneuron progenitors destined to become specific interneurons expressing PV, SST, or NPY directly from patient fibroblasts in the near future. Such approach would eliminate the presence PSCs in the cell suspension chosen for grafting. Because development of these new exciting approaches would need time, clinical translation of GABA-ergic progenitor cell therapy for epilepsy is likely to progress slowly but steadily in the coming years.

\section{Conclusions}

GABA-ergic progenitors derived from multiple sources can reduce SRS with grafting performed to epileptic brain regions at variable time-points after an episode of acute seizure activity, the commencement of SRS activity, or insult. This has been demonstrated in animal prototypes of SE, chronic TLE, kindling and absence seizures, and in mutant mice displaying SRS. Some studies have also reported improvements in short-term spatial and working memory and calming effects on aggression in epileptic animals. These results are exciting but addressing 
issues detailed in section 4 above through additional studies is critical for paving the way for clinical translation of GABA-ergic cell grafting for epileptic conditions. 


\section{Acknowledgments}

This work was supported by grants from the Department of Defense (PRMRP award, W81XWH-14-1-0558 to A.K.S.), the Department of Veterans Affairs (VA Merit Award, I01 BX002351 to A.K.S.) and the State of Texas (Emerging Technology Funds to A.K.S.). Authors thank Drs. B. Hattiangady, M. S. Rao, R. Kuruba, B. Shuai, and B. Waldau for their excellent contributions to Shetty Lab grafting studies in epilepsy models discussed in this review and Mr. Luciano Silveira for his contribution to preparation of figures. Dr. A. Shetty is also Research Career Scientist at the Olin E. Teague Veterans' Medical Center, Central Texas Veterans Health Care System Temple, Texas. Dr. Upadhya is an Assistant Professor on study leave from S.D.M. College of Ayurveda, Udupi, India.

\section{Department of Defense and Department of Veterans Affairs/United States Government Disclaimer}

The contents of this article suggest the views of authors and do not represent the views of the U.S. Department of Defense, Department of Veterans Affairs or the United States Government. 


\section{References}

Agadi, S., Shetty, A.K., 2015. Concise review: Prospects of bone marrow mononuclear cells and mesenchymal stem cells for treating status epilepticus and chronic epilepsy. Stem Cells.

Alvarez-Dolado, M., Calcagnotto, M.E., Karkar, K.M., Southwell, D.G., Jones-Davis, D.M., Estrada, R.C., Rubenstein, J.L., Alvarez-Buylla, A., Baraban, S.C., 2006. Cortical inhibition modified by embryonic neural precursors grafted into the postnatal brain. J Neurosci. 26, 7380-7389.

Andrade, D.M., Zumsteg, D., Hamani, C., Hodaie, M., Sarkissian, S., Lozano, A.M., Wennberg, R.A., 2006. Long-term follow-up of patients with thalamic deep brain stimulation for epilepsy. Neurology. 66, 1571-1573.

Au, E., Ahmed, T., Karayannis, T., Biswas, S., Gan, L., Fishell, G., 2013. A modular gain-offunction approach to generate cortical interneuron subtypes from ES cells. Neuron. 80, 1145-1158.

Baraban, S.C., Southwell, D.G., Estrada, R.C., Jones, D.L., Sebe, J.Y., Alfaro-Cervello, C., GarciaVerdugo, J.M., Rubenstein, J.L., Alvarez-Buylla, A., 2009. Reduction of seizures by transplantation of cortical GABAergic interneuron precursors into Kv1.1 mutant mice. Proc Natl Acad Sci U S A. 106, 15472-15477.

Ben-Ari, Y., 2006. Seizures beget seizures: the quest for GABA as a key player. Crit Rev Neurobiol. 18, 135-144.

Brundin, P., Kordower, J.H., 2012. Neuropathology in transplants in Parkinson's disease: implications for disease pathogenesis and the future of cell therapy. Prog Brain Res. 200, 221-241.

Buckmaster, P.S., 2014. Does mossy fiber sprouting give rise to the epileptic state? Adv Exp Med Biol. 813, 161-168.

Calcagnotto, M.E., Ruiz, L.P., Blanco, M.M., Santos-Junior, J.G., Valente, M.F., Patti, C., FrussaFilho, R., Santiago, M.F., Zipancic, I., Alvarez-Dolado, M., Mello, L.E., Longo, B.M., 2010. Effect of neuronal precursor cells derived from medial ganglionic eminence in an acute epileptic seizure model. Epilepsia. 51 Suppl 3, 71-75.

Castillo, C.G., Mendoza, S., Freed, W.J., Giordano, M., 2006. Intranigral transplants of immortalized GABAergic cells decrease the expression of kainic acid-induced seizures in the rat. Behav Brain Res. 171, 109-115.

Castillo, C.G., Mendoza-Trejo, S., Aguilar, M.B., Freed, W.J., Giordano, M., 2008. Intranigral transplants of a GABAergic cell line produce long-term alleviation of established motor seizures. Behav Brain Res. 193, 17-27.

Chen, Y.J., Vogt, D., Wang, Y., Visel, A., Silberberg, S.N., Nicholas, C.R., Danjo, T., Pollack, J.L., Pennacchio, L.A., Anderson, S., Sasai, Y., Baraban, S.C., Kriegstein, A.R., Alvarez-Buylla, A., Rubenstein, J.L., 2013. Use of "MGE enhancers" for labeling and selection of embryonic stem cell-derived medial ganglionic eminence (MGE) progenitors and neurons. PLoS One. 8, e61956.

Cornish, S.M., Wheal, H.V., 1989. Long-term loss of paired pulse inhibition in the kainic acidlesioned hippocampus of the rat. Neuroscience. 28, 563-571.

Cronin, J., Dudek, F.E., 1988. Chronic seizures and collateral sprouting of dentate mossy fibers after kainic acid treatment in rats. Brain Res. 474, 181-184.

Cukiert, A., Mariani, P.P., Burattini, J.A., Cukiert, C.M., Forster, C., Baise, C., Argentoni-Baldochi, M., Mello, V., 2010. Vagus nerve stimulation might have a unique effect in reflex eating seizures. Epilepsia. 51, 301-303.

Cunningham, M., Cho, J.H., Leung, A., Savvidis, G., Ahn, S., Moon, M., Lee, P.K., Han, J.J., Azimi, N., Kim, K.S., Bolshakov, V.Y., Chung, S., 2014. hPSC-derived maturing GABAergic interneurons ameliorate seizures and abnormal behavior in epileptic mice. Cell Stem Cell. 15, 559-573. 
De la Cruz, E., Zhao, M., Guo, L., Ma, H., Anderson, S.A., Schwartz, T.H., 2011. Interneuron progenitors attenuate the power of acute focal ictal discharges. Neurotherapeutics. 8, 763773.

DeGiorgio, C.M., Schachter, S.C., Handforth, A., Salinsky, M., Thompson, J., Uthman, B., Reed, R., Collins, S., Tecoma, E., Morris, G.L., Vaughn, B., Naritoku, D.K., Henry, T., Labar, D., Gilmartin, R., Labiner, D., Osorio, I., Ristanovic, R., Jones, J., Murphy, J., Ney, G., Wheless, J., Lewis, P., Heck, C., 2000. Prospective long-term study of vagus nerve stimulation for the treatment of refractory seizures. Epilepsia. 41, 1195-1200.

Deng, W., Aimone, J.B., Gage, F.H., 2010. New neurons and new memories: how does adult hippocampal neurogenesis affect learning and memory? Nat Rev Neurosci. 11, 339-350.

Devinsky, O., 2004. Diagnosis and treatment of temporal lobe epilepsy. Rev Neurol Dis. 1, 2-9.

During, M.J., Ryder, K.M., Spencer, D.D., 1995. Hippocampal GABA transporter function in temporal-lobe epilepsy. Nature. 376, 174-177.

Esclapez, M., Trottier, S., 1989. Changes in GABA-immunoreactive cell density during motor focal epilepsy induced by cobalt in the rat. Exp Brain Res. 76, 369-385.

Gallego, J.M., Sancho, F.J., Vidueira, S., Ortiz, L., Gomez-Pinedo, U., Barcia, J.A., 2010. Injection of embryonic median ganglionic eminence cells or fibroblasts within the amygdala in rats kindled from the piriform cortex. Seizure. 19, 461-466.

Gernert, M., Thompson, K.W., Loscher, W., Tobin, A.J., 2002. Genetically engineered GABAproducing cells demonstrate anticonvulsant effects and long-term transgene expression when transplanted into the central piriform cortex of rats. Exp Neurol. 176, 183-192.

Gilad, R., 2012. Management of seizures following a stroke: what are the options? Drugs Aging. 29:533-538.

Hammad, M., Schmidt, S.L., Zhang, X., Bray, R., Frohlich, F., Ghashghaei, H.T., 2014. Transplantation of GABAergic Interneurons into the Neonatal Primary Visual Cortex Reduces Absence Seizures in Stargazer Mice. Cereb Cortex.

Handreck, A., Backofen-Wehrhahn, B., Broer, S., Loscher, W., Gernert, M., 2014. Anticonvulsant effects by bilateral and unilateral transplantation of GABA-producing cells into the subthalamic nucleus in an acute seizure model. Cell Transplant. 23, 111-132.

Hattiangady, B., Rao, M.S., Shetty, A.K., 2004. Chronic temporal lobe epilepsy is associated with severely declined dentate neurogenesis in the adult hippocampus. Neurobiol Dis. 17, 473490.

Hattiangady, B., Rao, M.S., Zaman, V., Shetty, A.K., 2006. Incorporation of embryonic CA3 cell grafts into the adult hippocampus at 4-months after injury: effects of combined neurotrophic supplementation and caspase inhibition. Neuroscience. 139, 1369-1383.

Hattiangady, B., Rao, M.S., Shetty, A.K., 2008. Grafting of striatal precursor cells into hippocampus shortly after status epilepticus restrains chronic temporal lobe epilepsy. Exp Neurol. 212, 468-481.

Hattiangady, B., Shetty, A.K., 2010. Decreased neuronal differentiation of newly generated cells underlies reduced hippocampal neurogenesis in chronic temporal lobe epilepsy. Hippocampus. 20, 97-112.

Hattiangady, B., Liu, Y., Shuai, B., Yao, L., Rao, X., Zhang, S.-C., Shetty, A.K., 2013. Survival, differentiation and functional effects of human iPSC-derived MGE progenitor cells in a model of temporal lobe epilepsy. Society for Neuroscience Abstracts, 414.18/C19.

Henderson, K.W., Gupta, J., Tagliatela, S., Litvina, E., Zheng, X., Van Zandt, M.A., Woods, N., Grund, E., Lin, D., Royston, S., Yanagawa, Y., Aaron, G.B., Naegele, J.R., 2014. Long-term seizure suppression and optogenetic analyses of synaptic connectivity in epileptic mice with hippocampal grafts of GABAergic interneurons. J Neurosci. 34, 13492-13504.

Houser, C.R., 2014. Do structural changes in GABA neurons give rise to the epileptic state? Adv Exp Med Biol. 813, 151-160. 
Hunt, R.F., Girskis, K.M., Rubenstein, J.L., Alvarez-Buylla, A., Baraban, S.C., 2013. GABA progenitors grafted into the adult epileptic brain control seizures and abnormal behavior. Nat Neurosci. 16, 692-697.

Jobst, B.C., Cascino, G.D., 2015. Resective epilepsy surgery for drug-resistant focal epilepsy: a review. JAMA. 313, 285-293.

Kobayashi, M., Buckmaster, P.S., 2003. Reduced inhibition of dentate granule cells in a model of temporal lobe epilepsy. J Neurosci. 23, 2440-2452.

Kokaia, M., Aebischer, P., Elmer, E., Bengzon, J., Kalen, P., Kokaia, Z., Lindvall, O., 1994. Seizure suppression in kindling epilepsy by intracerebral implants of GABA- but not by noradrenaline-releasing polymer matrices. Exp Brain Res. 100, 385-394.

Kossoff, E.H., Rowley, H., Sinha, S.R., Vining, E.P., 2008. A prospective study of the modified Atkins diet for intractable epilepsy in adults. Epilepsia. 49, 316-319.

Kuruba, R., Hattiangady, B., Parihar, V.K., Shuai, B., Shetty, A.K., 2011. Differential susceptibility of interneurons expressing neuropeptide $Y$ or parvalbumin in the aged hippocampus to acute seizure activity. PLoS One. 6, e24493.

Kwan, P., Arzimanoglou, A., Berg, A.T., Brodie, M.J., Allen Hauser, W., Mathern, G., Moshe, S.L., Perucca, E., Wiebe, S., French, J., 2010. Definition of drug resistant epilepsy: consensus proposal by the ad hoc Task Force of the ILAE Commission on Therapeutic Strategies. Epilepsia. 51, 1069-1077.

Lee, H., Yun, S., Kim, I.S., Lee, I.S., Shin, J.E., Park, S.C., Kim, W.J., Park, K.I., 2014. Human fetal brain-derived neural stem/progenitor cells grafted into the adult epileptic brain restrain seizures in rat models of temporal lobe epilepsy. PLoS One. 9, e104092.

Lewis, D.V., 2005. Losing neurons: selective vulnerability and mesial temporal sclerosis. Epilepsia. 46 Suppl 7, 39-44.

Liu, Y., Liu, H., Sauvey, C., Yao, L., Zarnowska, E.D., Zhang, S.C., 2013a. Directed differentiation of forebrain GABA interneurons from human pluripotent stem cells. Nat Protoc. 8, 16701679.

Liu, Y., Weick, J.P., Liu, H., Krencik, R., Zhang, X., Ma, L., Zhou, G.M., Ayala, M., Zhang, S.C., 2013b. Medial ganglionic eminence-like cells derived from human embryonic stem cells correct learning and memory deficits. Nat Biotechnol. 31, 440-447.

Lloyd, K.G., Bossi, L., Morselli, P.L., Munari, C., Rougier, M., Loiseau, H., 1986. Alterations of GABA-mediated synaptic transmission in human epilepsy. Adv Neurol. 44, 1033-1044.

Loscher, W., Ebert, U., Lehmann, H., Rosenthal, C., Nikkhah, G., 1998. Seizure suppression in kindling epilepsy by grafts of fetal GABAergic neurons in rat substantia nigra. J Neurosci Res. 51, 196-209.

Loscher, W., Gernert, M., Heinemann, U., 2008. Cell and gene therapies in epilepsy--promising avenues or blind alleys? Trends Neurosci. 31, 62-73.

Lucke-Wold, B.P., Nguyen, L., Turner, R.C., Logsdon, A.F., Chen, Y.W., Smith, K.E., Huber, J.D., Matsumoto, R., Rosen, C.L., Tucker, E.S., Richter, E., 2015. Traumatic brain injury and epilepsy: Underlying mechanisms leading to seizure. Seizure 33:13-23.

Magloczky, Z., Halasz, P., Vajda, J., Czirjak, S., Freund, T.F., 1997. Loss of Calbindin-D28K immunoreactivity from dentate granule cells in human temporal lobe epilepsy. Neuroscience. 76, 377-385.

Maisano, X., Litvina, E., Tagliatela, S., Aaron, G.B., Grabel, L.B., Naegele, J.R., 2012. Differentiation and functional incorporation of embryonic stem cell-derived GABAergic interneurons in the dentate gyrus of mice with temporal lobe epilepsy. J Neurosci. 32, 4661.

Maroof, A.M., Brown, K., Shi, S.H., Studer, L., Anderson, S.A., 2010. Prospective isolation of cortical interneuron precursors from mouse embryonic stem cells. J Neurosci. 30, 46674675. 
Maroof, A.M., Keros, S., Tyson, J.A., Ying, S.W., Ganat, Y.M., Merkle, F.T., Liu, B., Goulburn, A., Stanley, E.G., Elefanty, A.G., Widmer, H.R., Eggan, K., Goldstein, P.A., Anderson, S.A., Studer, L., 2013. Directed differentiation and functional maturation of cortical interneurons from human embryonic stem cells. Cell Stem Cell. 12, 559-572.

Nagerl, U.V., Mody, I., Jeub, M., Lie, A.A., Elger, C.E., Beck, H., 2000. Surviving granule cells of the sclerotic human hippocampus have reduced $\mathrm{Ca}(2+)$ influx because of a loss of calbindin-D(28k) in temporal lobe epilepsy. J Neurosci. 20, 1831-1836.

Nicholas, C.R., Chen, J., Tang, Y., Southwell, D.G., Chalmers, N., Vogt, D., Arnold, C.M., Chen, Y.J., Stanley, E.G., Elefanty, A.G., Sasai, Y., Alvarez-Buylla, A., Rubenstein, J.L., Kriegstein, A.R., 2013. Functional maturation of hPSC-derived forebrain interneurons requires an extended timeline and mimics human neural development. Cell Stem Cell. 12, 573-586.

Nolte, M.W., Loscher, W., Herden, C., Freed, W.J., Gernert, M., 2008. Benefits and risks of intranigral transplantation of GABA-producing cells subsequent to the establishment of kindling-induced seizures. Neurobiol Dis. 31, 342-354.

Okano, H., Nakamura, M., Yoshida, K., Okada, Y., Tsuji, O., Nori, S., Ikeda, E., Yamanaka, S., Miura, K., 2013. Steps toward safe cell therapy using induced pluripotent stem cells. Circ Res. 112, 523-533.

Raedt, R., Van Dycke, A., Waeytens, A., Wyckhuys, T., Vonck, K., Wadman, W., Boon, P., 2009. Unconditioned adult-derived neurosphere cells mainly differentiate towards astrocytes upon transplantation in sclerotic rat hippocampus. Epilepsy Res. 87:148-159.

Rao, M.S., Hattiangady, B., Shetty, A.K., 2006. Fetal hippocampal CA3 cell grafts enriched with FGF-2 and BDNF exhibit robust long-term survival and integration and suppress aberrant mossy fiber sprouting in the injured middle-aged hippocampus. Neurobiol Dis. 21, 276-290.

Rao, M.S., Hattiangady, B., Rai, K.S., Shetty, A.K., 2007. Strategies for promoting anti-seizure effects of hippocampal fetal cells grafted into the hippocampus of rats exhibiting chronic temporal lobe epilepsy. Neurobiol Dis. 27, 117-132.

Shetty, A.K., Turner, D.A., 1995. Enhanced cell survival in fetal hippocampal suspension transplants grafted to adult rat hippocampus following kainate lesions: a three-dimensional graft reconstruction study. Neuroscience. 67, 561-582.

Shetty, A.K., Turner, D.A., 1997a. Development of long-distance efferent projections from fetal hippocampal grafts depends upon pathway specificity and graft location in kainate-lesioned adult hippocampus. Neuroscience. 76, 1205-1219.

Shetty, A.K., Turner, D.A., 1997b. Fetal hippocampal cells grafted to kainate-lesioned CA3 region of adult hippocampus suppress aberrant supragranular sprouting of host mossy fibers. Exp Neurol. 143, 231-245.

Shetty, A.K., Turner, D.A., 2000. Fetal hippocampal grafts containing CA3 cells restore host hippocampal glutamate decarboxylase-positive interneuron numbers in a rat model of temporal lobe epilepsy. J Neurosci. 20, 8788-8801.

Shetty, A.K., Zaman, V., Turner, D.A., 2000. Pattern of long-distance projections from fetal hippocampal field CA3 and CA1 cell grafts in lesioned CA3 of adult hippocampus follows intrinsic character of respective donor cells. Neuroscience. 99, 243-255.

Shetty, A.K., Zaman, V., Shetty, G.A., 2003. Hippocampal neurotrophin levels in a kainate model of temporal lobe epilepsy: a lack of correlation between brain-derived neurotrophic factor content and progression of aberrant dentate mossy fiber sprouting. J Neurochem. 87, 147159.

Shetty, A.K., Zaman, V., Hattiangady, B., 2005. Repair of the injured adult hippocampus through graft-mediated modulation of the plasticity of the dentate gyrus in a rat model of temporal lobe epilepsy. J Neurosci. 25, 8391-8401.

Shetty, A.K., Hattiangady, B., 2007a. Concise review: prospects of stem cell therapy for temporal lobe epilepsy. Stem Cells. 25, 2396-2407. 
Shetty, A.K., Hattiangady, B., 2007b. Restoration of calbindin after fetal hippocampal CA3 cell grafting into the injured hippocampus in a rat model of temporal lobe epilepsy. Hippocampus. 17, 943-956.

Shetty, A.K., Hattiangady, B., Rao, M.S., 2009. Vulnerability of hippocampal GABA-ergic interneurons to kainate-induced excitotoxic injury during old age. J Cell Mol Med. 13, 24082423.

Shetty, A.K., 2011. Progress in cell grafting therapy for temporal lobe epilepsy. Neurotherapeutics. 8, 721-735.

Shetty, A.K., 2014. Hippocampal injury-induced cognitive and mood dysfunction, altered neurogenesis, and epilepsy: can early neural stem cell grafting intervention provide protection? Epilepsy Behav. 38, 117-124.

Shetty, A.K., Hattiangady, B., Shuai, B., Rao, X., 2014. GABA-ergic cell therapy greatly diminishes spontaneous seizures and alleviates cognitive and mood dysfunction in chronic temporal lobe epilepsy. Epilepsy Currents. 14 (s1), 27-28. AES 2013 Annual Meeting-Online Abstract Supplement), pp. 27-28. doi: http://dx.doi.org/10.5698/1535-7511-14.s1.1

Sierra, A., Martin-Suarez, S., Valcarcel-Martin, R., Pascual-Brazo, J., Aelvoet, S.A., Abiega, O., Deudero, J.J., Brewster, A.L., Bernales, I., Anderson, A.E., Baekelandt, V., Maletic-Savatic, M., Encinas, J.M., 2015. Neuronal hyperactivity accelerates depletion of neural stem cells and impairs hippocampal neurogenesis. Cell Stem Cell. 16, 488-503.

Sloviter, R.S., Zappone, C.A., Harvey, B.D., Bumanglag, A.V., Bender, R.A., Frotscher, M., 2003. "Dormant basket cell" hypothesis revisited: relative vulnerabilities of dentate gyrus mossy cells and inhibitory interneurons after hippocampal status epilepticus in the rat. $\mathrm{J}$ Comp Neurol. 459, 44-76.

Southwell, D.G., Froemke, R.C., Alvarez-Buylla, A., Stryker, M.P., Gandhi, S.P., 2010. Cortical plasticity induced by inhibitory neuron transplantation. Science. 327, 1145-1148.

Southwell, D.G., Nicholas, C.R., Basbaum, A.I., Stryker, M.P., Kriegstein, A.R., Rubenstein, J.L., Alvarez-Buylla, A., 2014. Interneurons from embryonic development to cell-based therapy. Science. 344, 1240622.

Stafstrom, C.E., 2014. Epilepsy comorbidities: how can animal models help? Adv Exp Med Biol. 813, 273-281.

Thompson, K.W., 2005. Genetically engineered cells with regulatable GABA production can affect afterdischarges and behavioral seizures after transplantation into the dentate gyrus. Neuroscience. 133, 1029-1037.

Tyson, J.A., Goldberg, E.M., Maroof, A.M., Xu, Q., Petros, T.J., Anderson, S.A., 2015. Duration of culture and sonic hedgehog signaling differentially specify PV versus SST cortical interneuron fates from embryonic stem cells. Development. 142, 1267-1278.

Uludag, I.F., Duksal, T., Tiftikcioglu, B.I., Zorlu, Y., Ozkaya, F., Kirkali, G., 2015. IL-1beta, IL-6 and IL1Ra levels in temporal lobe epilepsy. Seizure. 26, 22-25.

Waldau, B., Hattiangady, B., Kuruba, R., Shetty, A.K., 2010. Medial ganglionic eminence-derived neural stem cell grafts ease spontaneous seizures and restore GDNF expression in a rat model of chronic temporal lobe epilepsy. Stem Cells. 28, 1153-1164.

Wichterle, H., Garcia-Verdugo, J.M., Herrera, D.G., Alvarez-Buylla, A., 1999. Young neurons from medial ganglionic eminence disperse in adult and embryonic brain. Nat Neurosci. 2, 461466.

Wiebe, S., Blume, W.T., Girvin, J.P., Eliasziw, M., Effectiveness, Efficiency of Surgery for Temporal Lobe Epilepsy Study, G., 2001. A randomized, controlled trial of surgery for temporal-lobe epilepsy. N Engl J Med. 345, 311-318.

Wilcox, K.S., Vezzani, A., 2014. Does brain inflammation mediate pathological outcomes in epilepsy? Adv Exp Med Biol. 813, 169-183.

Wuarin, J.P., Dudek, F.E., 2001. Excitatory synaptic input to granule cells increases with time after kainate treatment. J Neurophysiol. 85, 1067-1077. 
Zaman, V., Turner, D.A., Shetty, A.K., 2001. Prolonged postlesion transplantation delay adversely influences survival of both homotopic and heterotopic fetal hippocampal cell grafts in Kainate-lesioned CA3 region of adult hippocampus. Cell Transplant. 10, 41-52.

Zaman, V., Shetty, A.K., 2003. Pretreatment of donor cells with FGF-2 enhances survival of fetal hippocampal CA3 cell transplants in the chronically lesioned young adult hippocampus. Exp Neurol. 183, 11-24.

Zipancic, I., Calcagnotto, M.E., Piquer-Gil, M., Mello, L.E., Alvarez-Dolado, M., 2010. Transplant of GABAergic precursors restores hippocampal inhibitory function in a mouse model of seizure susceptibility. Cell Transplant. 19, 549-564. 


\section{Figure Legends}

Figure1 - A schematic outlining the proposed migration, differentiation and integration of medial ganglionic eminence-like (MGE-like) gamma-amino butyric acid-ergic (GABA-ergic) progenitors following grafting into the epileptic hippocampus. Based on previous studies, it is proposed that placement of grafts at the end of hippocampal fissure is ideal as it causes negligible damage to principal cell layers of the hippocampus and facilitates migration of graft-derived neurons into the hilus, granule cell layer and molecular layer of the dentate gyrus (DG) and different layers of CA1 and CA3 subfields. The placement of graft is shown through an elliptical area containing GABAergic neurons (red color) bounded by black interrupted lines and migrated GABA-ergic neurons from the graft core are shown in different hippocampal subfields. It is hypothesized that graftderived GABA-ergic neurons receive glutamatergic afferent connections from all major classes of host principal neurons. The figure shows: (i) an example of a dentate granule cell (blue colored neuron in the DG) with its mossy fiber axon extending into the CA3 region and its axon collaterals establishing excitatory glutamatergic synapses (indicated by "+" sign) on graft-derived GABA-ergic neurons (red colored neurons); (ii) an example of a CA3 pyramidal neuron (green colored neuron) with its axon collateral (Schaffer collateral) extending into the CA1 subfield and its axonal branches establishing excitatory glutamatergic synapses (+) on graft-derived GABA-ergic neurons; and (iii) an example of a CA1 pyramidal neuron (black colored neuron) with its axon collaterals establishing excitatory glutamatergic synapses (+) on graft-derived GABA-ergic neurons. It is also envisioned that axons from different subclasses of GABA-ergic neurons derived from grafts (red colored neurons) would establish inhibitory synaptic contacts (indicated by "-" sign) on soma and/or dendrites of dentate granule cells and CA1 and CA3 pyramidal neurons. Thus, because of the possible integration of graft-host neurons as described above, it is likely that transplanted GABAergic neurons get activated through glutamatergic input from the host principal neurons, which sequentially results in propagation of strong inhibitory input from graft-derived GABA-ergic neurons onto host principal neurons, dampening of hyperactivity in principal neurons and reduced occurrence of seizures. DH, dentate hilus; GCL, granule cell layer; and HF, hippocampal fissure.

Figure 2 - A schematic portraying a series of steps required for establishing patient-specific medial ganglionic eminence-like (MGE-like) gamma-amino butyric acid-ergic (GABA-ergic) cell therapy for epilepsy. The steps encompass procuring a skin biopsy from the patient (a), separation of skin fibroblasts (b), reprogramming fibroblasts through insertion of transcription factors such as Sox-2, Oct-4, C-Myc and Klf-4 in culture (c), generation of induced pluripotent stem cell (iPSC) clones (d), 
expansion of iPSCs as embryoid bodies (e), directing iPSCs towards a neural lineage through treatment with neural induction factors and generation of neural rosettes (f), expansion and patterning of rosette cells (neuroepithelial cells) as neurospheres in a sonic hedgehog (Shh) containing medium to direct the transformation of NSCs into Nkx2.1 expressing MGE-like progenitors ( $\mathrm{g}$ and $\mathrm{h}$ ). Virtually all Nkx2.1+ cells give rise to GABA-ergic neurons, which can be visualized in culture through incubation in an appropriate neuronal differentiation medium (i). Following the establishment of iPSC clones from patients, the period for preparing the required number of MGE-like GABA-ergic progenitors for grafting is estimated to be 25-30 days.

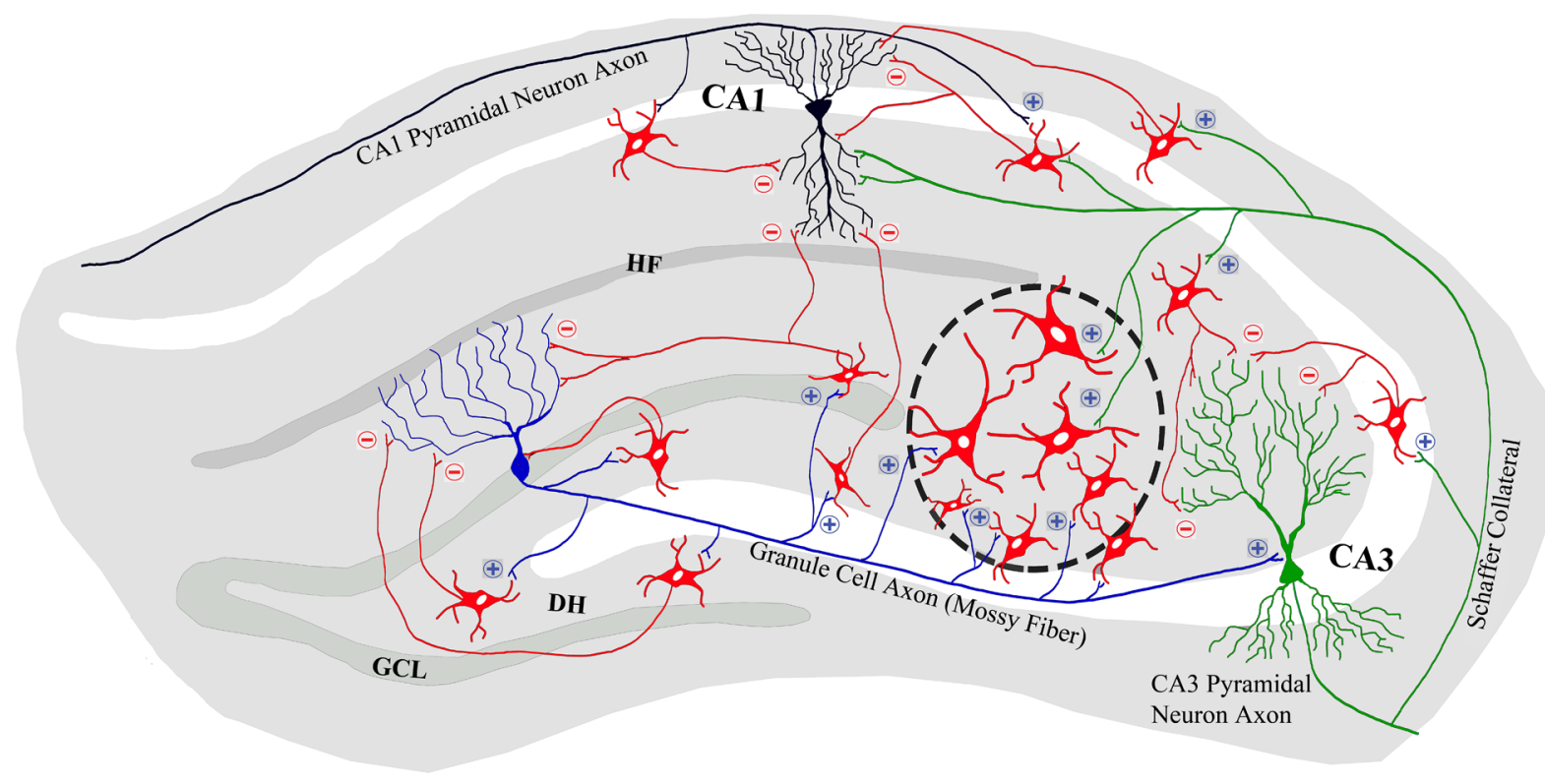

FIGURE 1 


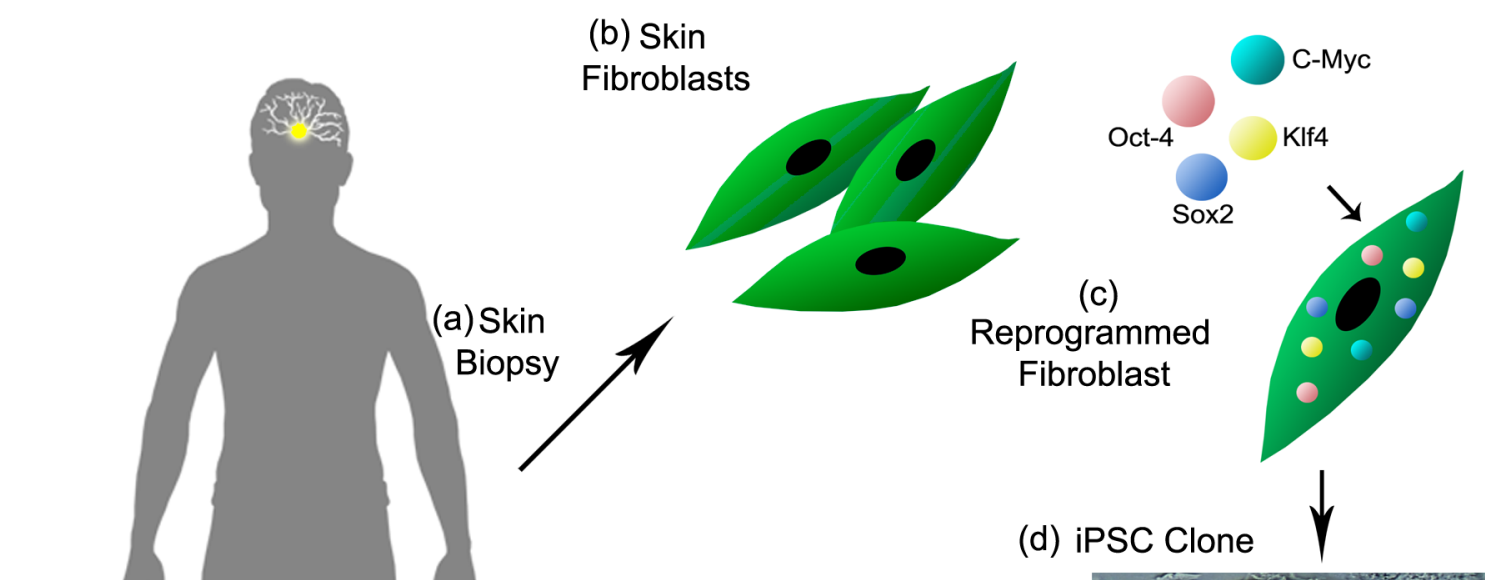

Epileptic

Patient

Transplantation

into the Epileptic

Hippocampus

(i) GABA-ergic Neurons
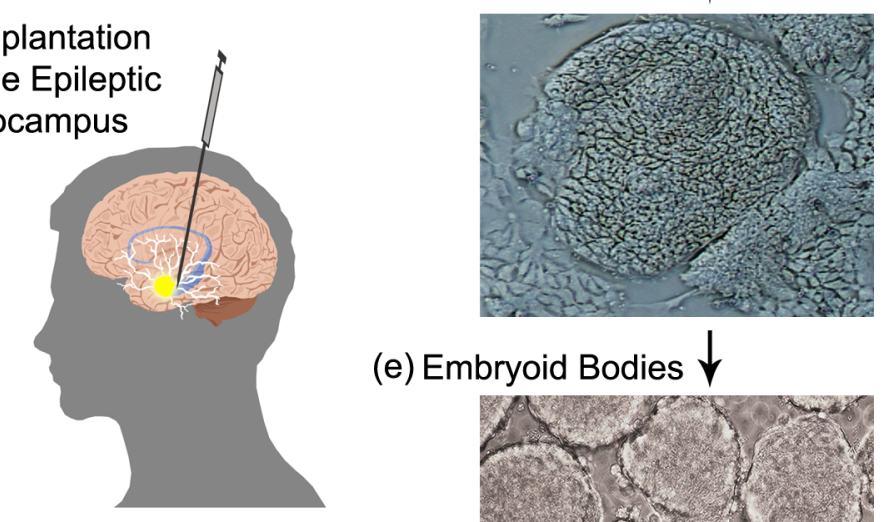

(e) Embryoid Bodies $\downarrow$
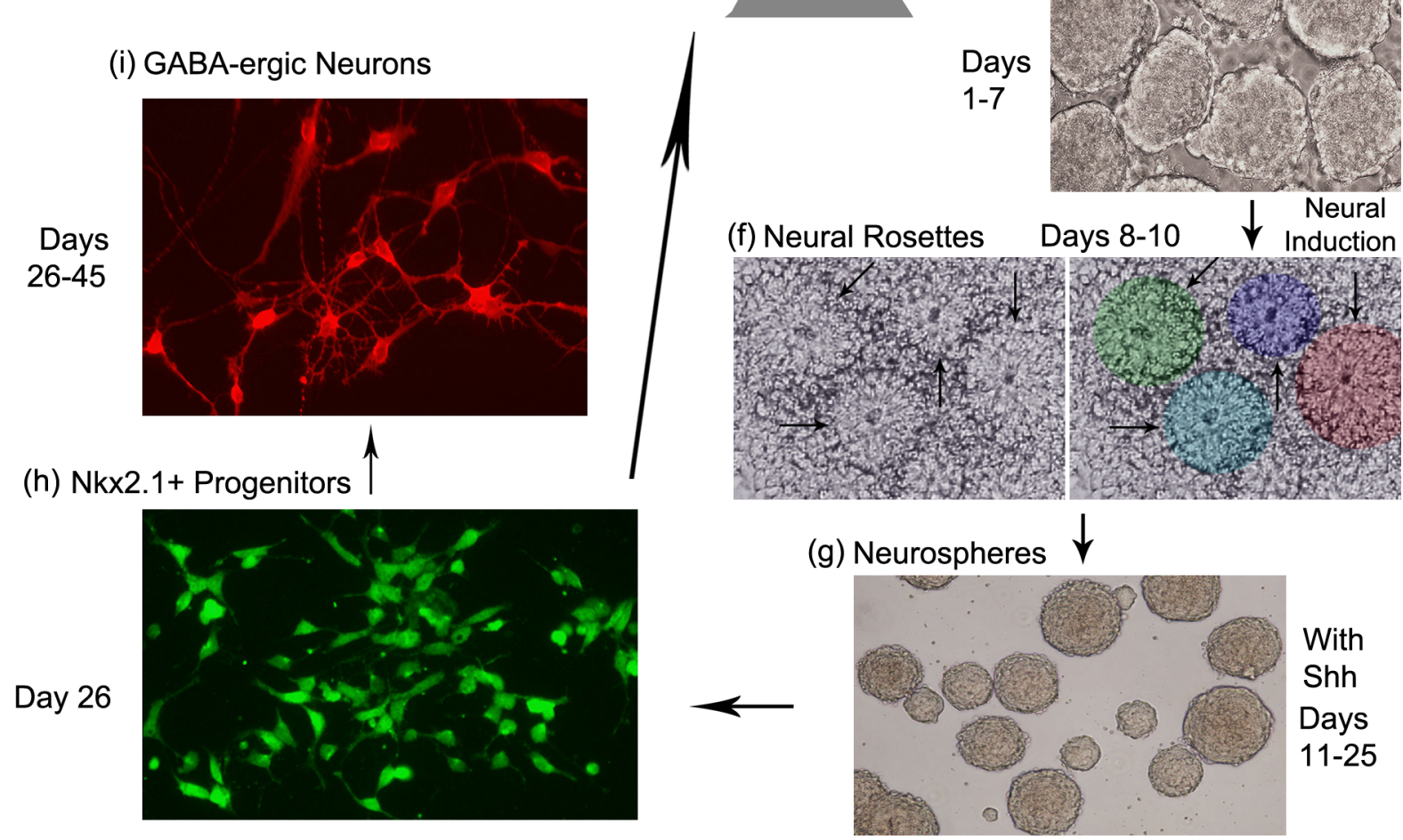

FIGURE 2 
Table 1 - Early Intervention or Prophylactic Studies of Primary GABA-ergic Cell Grafts in Epilepsy Models (2008-present)

\begin{tabular}{|c|c|c|c|c|c|}
\hline $\begin{array}{l}\text { Animal Prototype } \\
\text { and Type of Donor } \\
\text { Cells }\end{array}$ & $\begin{array}{l}\text { Timing and } \\
\text { Site of } \\
\text { Grafting }\end{array}$ & $\begin{array}{l}\text { Time-point } \\
\text { of Seizure } \\
\text { Analyses } \\
\text { \& Effects on } \\
\text { Seizures }\end{array}$ & $\begin{array}{l}\text { Effects } \\
\text { on } \\
\text { Memoryl } \\
\text { Mood } \\
\text { Function }\end{array}$ & $\begin{array}{l}\text { Graft Cell } \\
\text { Survival, } \\
\text { Differentiation } \\
\text { and Integration }\end{array}$ & $\begin{array}{l}\text { Effects of } \\
\text { Grafts on } \\
\text { Epileptogenic } \\
\text { Changes in } \\
\text { the Host Brain }\end{array}$ \\
\hline $\begin{array}{l}\text { Kainate induced SE } \\
\text { in rats } \\
\text { Gamma-amino } \\
\text { butyric acid positive } \\
\text { (GABA-ergic) } \\
\text { progenitors from the } \\
\text { embryonic day } 15 \\
\text { (E15) rat lateral } \\
\text { ganglionic eminence } \\
\text { (LGE) treated with } \\
\text { fibroblast growth } \\
\text { factor-2 } \\
\text { Hattiangady et al., } \\
2008\end{array}$ & $\begin{array}{l}4 \text { days after } \\
\text { status } \\
\text { epilepticus } \\
\text { (SE) } \\
\text { Grafts placed } \\
\text { into the } \\
\text { Hippocampus }\end{array}$ & $\begin{array}{l}9-12 \text { months } \\
\text { after grafting } \\
67-89 \% \\
\text { decrease in } \\
\text { the frequency } \\
\text { spontaneous } \\
\text { recurrent } \\
\text { seizures } \\
\text { (SRS) }\end{array}$ & $\begin{array}{l}\text { Not } \\
\text { Assessed }\end{array}$ & $\begin{array}{l}\text { Recovery } \\
\text { equivalent to 33\% } \\
\text { of injected cells (at } \\
\text { one year post- } \\
\text { grafting) } \\
\text { Differentiated into } \\
\text { neurons expressing } \\
\text { GABA (69\%), } \\
\text { neuropeptide Y } \\
\text { (NPY, 8\%), } \\
\text { parvalbumin (PV, } \\
29 \%), \text { calbindin } \\
\text { (CBN, 30\%) \& } \\
\text { calretinin (CR, } \\
31 \%)\end{array}$ & 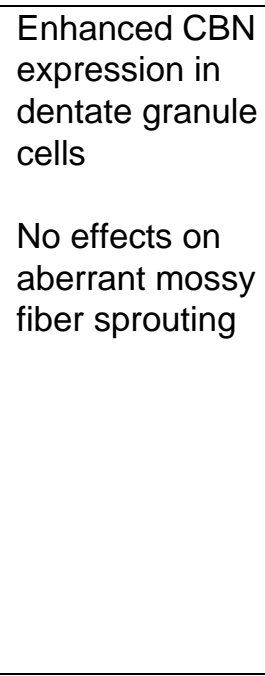 \\
\hline $\begin{array}{l}\text { Shaker-like } \\
\text { potassium channel } \\
(K v 1.1 / K c n a 1) \text { mutant } \\
\text { mouse } \\
\text { GABA-ergic } \\
\text { progenitors from the } \\
\text { E13.5 mouse medial } \\
\text { ganglionic eminence } \\
\text { (MGE) } \\
\text { Baraban et al., } 2009\end{array}$ & $\begin{array}{l}\text { Postnatal } \\
\text { Day } 2 \\
\text { Grafts placed } \\
\text { into the } \\
\text { neocortex }\end{array}$ & $\begin{array}{l}2^{\text {nd }} \text { month } \\
\text { after grafting } \\
\text { Significant } \\
\text { reductions in } \\
\text { the duration } \\
\text { and } \\
\text { frequency of } \\
\text { spontaneous } \\
\text { electrographi } \\
\text { c seizures }\end{array}$ & $\begin{array}{l}\text { Not } \\
\text { Assessed }\end{array}$ & $\begin{array}{l}\text { Survival: \% not } \\
\text { reported. } \\
\text { Differentiated into } \\
\text { neurons expressing } \\
\text { GABA (65\%), PV } \\
(29 \%), \\
\text { somatostatin (SST, } \\
\text { 44\%), NPY (10\%) } \\
\& \text { CR }(5 \%)\end{array}$ & Not Examined \\
\hline $\begin{array}{l}\text { Mouse model of } \\
\text { seizure vulnerability } \\
\text { induced by an } \\
\text { injection of SSP-Sap } \\
\text { (a conjugate of } \\
\text { peptidase-resistant } \\
{\left[\text { Sar }^{9}, \text { Met }\left(\mathrm{O}_{2}\right)^{11}\right]} \\
\text { analog of substance } \\
\mathrm{P} \text { and the ribosome- } \\
\text { inactivating protein } \\
\text { saporin) } \\
\text { GABA-ergic } \\
\text { progenitors from the } \\
\text { E12.5 mouse MGE } \\
\text { Zipancic et al., } 2010\end{array}$ & $\begin{array}{l}\text { 1-week after } \\
\text { injection of } \\
\text { SSP-Sap } \\
\text { Grafts placed } \\
\text { into the } \\
\text { Hippocampus }\end{array}$ & $\begin{array}{l}\text { 2-months } \\
\text { after SSP- } \\
\text { Sap injection } \\
\text { Significantly } \\
\text { decreased } \\
\text { sensitivity } \\
\text { and } \\
\text { diminished } \\
\text { mortality to } \\
\text { pentylenetetr } \\
\text { azol (PTZ) } \\
\text { induced } \\
\text { seizures }\end{array}$ & $\begin{array}{l}\text { Not } \\
\text { Assessed }\end{array}$ & $\begin{array}{l}\text { Survival: } 18-20 \% \text { at } \\
2-12 \text { months post- } \\
\text { grafting } \\
\text { Differentiated into } \\
\text { neurons expressing } \\
\text { GABA (65\%), PV } \\
\text { (35\%), SST (34\%), } \\
\text { NPY (19\%), } \\
\text { neurokinin-1 (NK-1, } \\
26 \%) \& \text { CR (4\%) }\end{array}$ & $\begin{array}{l}\text { Grafting } \\
\text { normalized } \\
\text { inhibitory } \\
\text { postsynaptic } \\
\text { current (IPSC) } \\
\text { frequency and } \\
\text { amplitude in } \\
\text { the CA1 } \\
\text { pyramidal } \\
\text { neurons }\end{array}$ \\
\hline
\end{tabular}




\begin{tabular}{|c|c|c|c|c|c|}
\hline $\begin{array}{l}\text { A mouse model of } \\
\text { maximum } \\
\text { electroconvulsive } \\
\text { shock (MES) } \\
\text { GABA-ergic } \\
\text { progenitors from the } \\
\text { mouse embryonic } \\
\text { MGE } \\
\text { Calcagnotto et al., } \\
2010\end{array}$ & $\begin{array}{l}\text { Neonatal } \\
\text { mice } \\
\text { Grafts placed } \\
\text { into the } \\
\text { cortex }\end{array}$ & $\begin{array}{l}\text { Two months } \\
\text { after grafting, } \\
\text { mice were } \\
\text { submitted to } \\
\text { MES } \\
\text { Grafting } \\
\text { altered the } \\
\text { course of } \\
\text { MES acute } \\
\text { seizures, } \\
\text { increased } \\
\text { seizure } \\
\text { threshold, } \\
\text { and/or } \\
\text { blocked the } \\
\text { generalized } \\
\text { convulsive } \\
\text { activity }\end{array}$ & $\begin{array}{l}\text { Not } \\
\text { Assessed }\end{array}$ & $\begin{array}{l}\text { Survival: \% not } \\
\text { reported } \\
\text { Qualitative } \\
\text { assessment } \\
\text { showed graft- } \\
\text { derived cells } \\
\text { expressing GABA, } \\
\text { NPY, CR and PV. } \\
\text { Grafted cells } \\
\text { migrated into the } \\
\text { surrounding brain } \\
\text { regions }\end{array}$ & Not Examined \\
\hline $\begin{array}{l}\text { A rat model of } \\
\text { kindling epilepsy } \\
\text { GABA-ergic } \\
\text { progenitors from the } \\
\text { E14.5 rat MGE } \\
\text { Gallego et al., } 2010\end{array}$ & $\begin{array}{l}\text { 3-days after } \\
\text { full kindling } \\
\text { Grafts placed } \\
\text { into the } \\
\text { amygdala }\end{array}$ & $\begin{array}{l}\text { At 3-24 days } \\
\text { after grafting } \\
\text { Increased } \\
\text { after } \\
\text { discharge } \\
\text { and seizure } \\
\text { thresholds }\end{array}$ & $\begin{array}{l}\text { Not } \\
\text { Assessed }\end{array}$ & $\begin{array}{l}\text { Survival: qualitative } \\
\text { assessment } \\
\text { showed GABA+ } \\
\text { cells }\end{array}$ & Not Examined \\
\hline $\begin{array}{l}\text { A mouse model of 4- } \\
\text { aminopyridine (4-AP) } \\
\text { induced acute } \\
\text { epileptiform } \\
\text { discharges in the } \\
\text { neocortex } \\
\text { GABA-ergic } \\
\text { progenitors from the } \\
\text { mouse E13.5 MGE } \\
\text { De la Cruz et al., } \\
2011\end{array}$ & $\begin{array}{l}\text { 6-8 week old } \\
\text { mice } \\
\text { Grafts placed } \\
\text { into the } \\
\text { sensorimotor } \\
\text { cortex }\end{array}$ & $\begin{array}{l}\text { Injection of 4- } \\
\text { AP } \sim 2 \mathrm{~mm} \\
\text { away from } \\
\text { grafts at 2-8 } \\
\text { weeks post- } \\
\text { grafting } \\
\text { A dramatic } \\
\text { reduction in } \\
\text { local field } \\
\text { potential } \\
\text { power at the } \\
\text { MGE } \\
\text { transplanted } \\
\text { area }\end{array}$ & $\begin{array}{l}\text { Not } \\
\text { Assessed }\end{array}$ & $\begin{array}{l}\text { Survival: Exact } \\
\text { percentage not } \\
\text { reported. Semi- } \\
\text { quantitative } \\
\text { assessment } \\
\text { suggested lower } \\
\text { yield } \\
\\
\text { Graft-derived cells } \\
\text { differentiated into } \\
\text { neurons expressing } \\
\text { GABA (54-57\%), } \\
\text { SST (38-40\%) and } \\
\text { PV (13-17\%) }\end{array}$ & $\begin{array}{l}\text { Reduction in } \\
\text { ictal power did } \\
\text { not correlate } \\
\text { with graft cell } \\
\text { number, } \\
\text { implying the } \\
\text { presence of a } \\
\text { non-synpatic } \\
\text { mechanism }\end{array}$ \\
\hline
\end{tabular}


Table 2 - Studies of Medial Ganglionic Eminence (MGE) Cell Grafts in Prototypes Displaying Spontaneous Recurrent Seizures (SRS) or Absence Epilepsy

\begin{tabular}{|c|c|c|c|c|c|}
\hline $\begin{array}{l}\text { Animal } \\
\text { Prototype and } \\
\text { Type of Donor } \\
\text { Cells }\end{array}$ & $\begin{array}{l}\text { Timing and } \\
\text { Site of } \\
\text { Grafting }\end{array}$ & $\begin{array}{l}\text { Time-point of } \\
\text { Seizure Analyses } \\
\text { \& Effects on } \\
\text { Seizures }\end{array}$ & $\begin{array}{l}\text { Effects on } \\
\text { Memoryl } \\
\text { Mood } \\
\text { Function }\end{array}$ & $\begin{array}{l}\text { Graft Cell Survival, } \\
\text { Differentiation and } \\
\text { Integration }\end{array}$ & $\begin{array}{l}\text { Effects of } \\
\text { Grafts on } \\
\text { the Host } \\
\text { Brain } \\
\text { Changes }\end{array}$ \\
\hline $\begin{array}{l}\text { Pilocarpine } \\
\text { induced status } \\
\text { epilepticus (SE) } \\
\text { in mice } \\
\text { Gamma-amino } \\
\text { butyric acid } \\
\text { positive } \\
\text { (GABA-ergic) } \\
\text { progenitors } \\
\text { from the E13.5 } \\
\text { mouse medial } \\
\text { ganglionic } \\
\text { eminence } \\
\text { (MGE) } \\
\text { Hunt et al., } \\
2013\end{array}$ & $\begin{array}{l}\text {-20 days } \\
\text { after SE } \\
\text { (after the } \\
\text { occurrence of } \\
\text { SRS) } \\
\text { Grafts placed } \\
\text { into the } \\
\text { Hippocampus }\end{array}$ & $\begin{array}{l}\sim 2-\text { months after } \\
\text { grafting } \\
92 \% \text { reduction in } \\
\text { the frequency of } \\
\text { SRS, based on } \\
\text { continuous EEG for } \\
7-10 \text { days }\end{array}$ & $\begin{array}{l}\text { Grafting } \\
\text { alleviated } \\
\text { hyper- } \\
\text { activity, and } \\
\text { improved } \\
\text { short term } \\
\text { memory } \\
\text { retention } \\
\text { (based on a } \\
\text { probe test } \\
\text { performed } \\
\text { an hour } \\
\text { after the last } \\
\text { training } \\
\text { session) }\end{array}$ & $\begin{array}{l}\text { Precise percentages } \\
\text { of survival and } \\
\text { differentiation not } \\
\text { reported for epileptic } \\
\text { mice; A parallel } \\
\text { analyses in normal } \\
\text { mice revealed 33- } \\
15 \% \text { survival at 7-60 } \\
\text { days post-grafting, } \\
\text { and differentiation of } \\
\text { graft-derived cells } \\
\text { into subclasses of } \\
\text { interneurons } \\
\text { exhibiting fast- } \\
\text { spiking, regular- } \\
\text { spiking, late-spiking } \\
\text { and burst-spiking } \\
\text { properties }\end{array}$ & $\begin{array}{l}\text { No effect on } \\
\text { aberrant } \\
\text { mossy fiber } \\
\text { sprouting }\end{array}$ \\
\hline $\begin{array}{l}\text { Pilocarpine } \\
\text { induced SE in } \\
\text { mice } \\
\text { GABA-ergic } \\
\text { progenitors } \\
\text { from the E13.5 } \\
\text { mouse MGE } \\
\text { (vesicular } \\
\text { GABA } \\
\text { transporter } \\
\text { [VGAT]-Venus } \\
\text { and VGAT- } \\
\text { ChR2-GFP } \\
\text { mouse) } \\
\text { Henderson et } \\
\text { al., 2014 }\end{array}$ & $\begin{array}{l}\text { 2-weeks after } \\
\text { SE } \\
\text { Grafts placed } \\
\text { into the } \\
\text { Hippocampus }\end{array}$ & $\begin{array}{l}\text { 1-3 months after } \\
\text { grafting } \\
35 \% \text { reductions in } \\
\text { overall frequency of } \\
\text { SRS; } \\
\text { Reductions in SRS } \\
\text { duration and } \\
\text { severity } \\
\text { Seizure } \\
\text { suppressing effect } \\
\text { lost at an extended } \\
\text { time-point after } \\
\text { grafting }\end{array}$ & $\begin{array}{l}\text { Not } \\
\text { Assessed }\end{array}$ & $\begin{array}{l}\text { Percentage survival } \\
\text { not reported. } \\
\text { Graft-derived cells } \\
\text { differentiated into } \\
\text { interneurons } \\
\text { expressing } \\
\text { parvalbumin (PV, } \\
\text { 15\%), somatostatin } \\
\text { (SST, 25\%), } \\
\text { neuropeptide Y } \\
\text { (NPY, 36\%) \& } \\
\text { calbindin (CBN, } \\
42 \%) \\
\text { Graft cell derived } \\
\text { axons established } \\
\text { functional inhibitory } \\
\text { synaptic contacts on } \\
\text { soma, dendrites and } \\
\text { axons of host } \\
\text { granule cells }\end{array}$ & $\begin{array}{l}\text { Reduced } \\
\text { aberrant } \\
\text { mossy fiber } \\
\text { sprouting in } \\
\text { the vicinity of } \\
\text { MGE grafts } \\
\text { Increased } \\
\text { inhibitory } \\
\text { postsynaptic } \\
\text { currents } \\
\text { (IPSCs) in } \\
\text { granule cells }\end{array}$ \\
\hline $\begin{array}{l}\text { Kainate model } \\
\text { of chronic } \\
\text { temporal lobe } \\
\text { epilepsy (TLE) } \\
\text { in rat } \\
\text { GABA-ergic } \\
\text { progenitors }\end{array}$ & $\begin{array}{l}\text { Several } \\
\text { months after } \\
\text { SE } \\
\text { Grafts placed } \\
\text { into the } \\
\text { Hippocampus }\end{array}$ & $\begin{array}{l}2 \text { months after } \\
\text { grafting } \\
\text { 91-93\% reductions } \\
\text { in frequency and } \\
\text { duration of SRS } \\
\text { with elimination of } \\
\text { stage } V \text { seizures, in }\end{array}$ & $\begin{array}{l}\text { Improved } \\
\text { spatial } \\
\text { learning and } \\
\text { memory } \\
\text { function }\end{array}$ & $\begin{array}{l}\text { Survival: Recovery } \\
\text { equivalent to } \sim 30 \% \\
\text { of injected cells } \\
\text { Graft-derived cells } \\
\text { differentiated into } \\
\text { interneurons } \\
\text { expressing GABA }\end{array}$ & $\begin{array}{l}\text { Not } \\
\text { Examined }\end{array}$ \\
\hline
\end{tabular}




\begin{tabular}{|c|c|c|c|c|c|}
\hline $\begin{array}{l}\text { from the E14 } \\
\text { rat MGE } \\
\text { Shetty et al., } \\
2014\end{array}$ & & $\begin{array}{l}\text { comparison to pre- } \\
\text { grafting seizure } \\
\text { scores; } \\
\text { - 87\% reduction in } \\
\text { SRS frequency in } \\
\text { comparison to } \\
\text { epileptic animals } \\
\text { receiving no grafts }\end{array}$ & & $\begin{array}{l}\text { ( 91\%), NPY, SST, } \\
\text { PV, CBN \& calretinin } \\
\text { (CR) }\end{array}$ & \\
\hline $\begin{array}{l}\text { Stargazer } \\
\text { mouse model } \\
\text { of Absence } \\
\text { Epilepsy (AE) } \\
\text { GABA-ergic } \\
\text { progenitors } \\
\text { from the E12.5 } \\
\text { mouse MGE } \\
\text { Hammad et al., } \\
2014\end{array}$ & $\begin{array}{l}\text { Neonatal } \\
\text { mice (P0) } \\
\text { Grafts placed } \\
\text { into the } \\
\text { occipital } \\
\text { cortex }\end{array}$ & $\begin{array}{l}3 \text { weeks to } 4 \\
\text { months after } \\
\text { grafting } \\
\\
53-89 \% \text { reduction } \\
\text { in frequency and } \\
\text { duration of absence } \\
\text { seizure episodes; } \\
\text { Increased lifespan }\end{array}$ & $\begin{array}{l}\text { Not } \\
\text { assessed }\end{array}$ & $\begin{array}{l}\text { Percentage survival } \\
\text { not measured. Low } \\
\text { yield based on } \\
\text { counts/unit volume } \\
\text { Surviving graft- } \\
\text { derived cells } \\
\text { expressed GABA } \\
(93 \%), \\
\text { oligodendrocyte } \\
\text { transcription factor } 2 \\
\text { marker (Olig2, 14\%), } \\
\text { glial fibrillary acidic } \\
\text { protein (GFAP, 3\%) }\end{array}$ & $\begin{array}{l}\text { Normalization } \\
\text { of c-Fos } \\
\text { activity and } \\
\text { network } \\
\text { activity in } \\
\text { response to } \\
\text { an excitability } \\
\text { challenge }\end{array}$ \\
\hline
\end{tabular}


Table 3 - Studies on Stem Cell Grafts Generating GABA-ergic Cells in Epilepsy Models

\begin{tabular}{|c|c|c|c|c|c|}
\hline $\begin{array}{l}\text { Animal } \\
\text { Prototype and } \\
\text { Type of Donor } \\
\text { Cells }\end{array}$ & $\begin{array}{l}\text { Timing and } \\
\text { Site of } \\
\text { Grafting }\end{array}$ & $\begin{array}{l}\text { Time-point of } \\
\text { Seizure } \\
\text { Analyses } \\
\text { \& Effects on } \\
\text { Seizures }\end{array}$ & $\begin{array}{l}\text { Effects on } \\
\text { Memory and } \\
\text { Mood } \\
\text { Function }\end{array}$ & $\begin{array}{l}\text { Graft Cell } \\
\text { Survival, } \\
\text { Differentiation } \\
\text { and Integration }\end{array}$ & $\begin{array}{l}\text { Effects of } \\
\text { Grafts on } \\
\text { Host Brain } \\
\text { Changes }\end{array}$ \\
\hline $\begin{array}{l}\text { Kainate induced } \\
\text { rat model of } \\
\text { chronic temporal } \\
\text { lobe epilepsy } \\
\text { (TLE) } \\
\text { Neural stem } \\
\text { cells (NSCs) } \\
\text { expanded from } \\
\text { E14 rat medial } \\
\text { ganglionic } \\
\text { eminence (MGE) } \\
\text { Waldau et al., } \\
2010\end{array}$ & $\begin{array}{l}\text { 9-12 months } \\
\text { after the } \\
\text { induction of } \\
\text { status } \\
\text { epilepticus (SE) } \\
\text { - Rats } \\
\text { exhibiting } \\
\text { continuing } \\
\text { spontaneous } \\
\text { recurrent } \\
\text { seizures (SRS) } \\
\text { and learning } \\
\text { and memory } \\
\text { dysfunction } \\
\text { Grafts placed } \\
\text { into the } \\
\text { hippocampus }\end{array}$ & $\begin{array}{l}1-3 \text { months } \\
\text { post-grafting } \\
\text { Reduced the } \\
\text { frequency \& } \\
\text { duration of } \\
\text { SRS by } 43- \\
51 \%, \text { Stage-V } \\
\text { seizures by } \\
90 \% \text {, and the } \\
\text { total time } \\
\text { spent in } \\
\text { seizures by } \\
74 \%\end{array}$ & $\begin{array}{l}\text { No positive } \\
\text { effects of } \\
\text { grafts on } \\
\text { spatial } \\
\text { learning and } \\
\text { memory } \\
\text { function }\end{array}$ & $\begin{array}{l}\text { Recovery: } 28 \% \text { of } \\
\text { injected cells } \\
\text { Differentiation of } \\
\text { graft-derived cells: } \\
10 \% \text { into gamma- } \\
\text { amino butyric acid } \\
\text { positive (GABA- } \\
\text { ergic) neurons; } \\
57 \% \text { into S-100ß+ } \\
\text { astrocytes; and } \\
3 \% \text { into } \\
\text { oligodendrocyte } \\
\text { progenitors. } 50 \% \\
\text { of graft-derived } \\
\text { astrocytes also } \\
\text { expressed glial } \\
\text { cell-line derived } \\
\text { neurotrophic factor } \\
\text { (GDNF) }\end{array}$ & $\begin{array}{l}\text { Grafting } \\
\text { restored } \\
\text { GDNF in host } \\
\text { astrocytes } \\
\text { Grafting did } \\
\text { not enhance } \\
\text { neurogenesis } \\
\text { in the } \\
\text { hippocampus }\end{array}$ \\
\hline $\begin{array}{l}\text { Rat models of } \\
\text { kindling and } \\
\text { pilocarpine } \\
\text { induced TLE } \\
\text { NSCs from the } \\
\text { human } \\
\text { telencephalon of } \\
\text { aborted } 13 \\
\text { weeks gestation } \\
\text { fetus } \\
\text { Lee et al., } 2014\end{array}$ & $\begin{array}{l}\text { After full } \\
\text { kindling or 3- } \\
\text { weeks after SE } \\
\text { (i.e. after the } \\
\text { occurrence of } \\
\text { SRS) }\end{array}$ & $\begin{array}{l}2 \text { weeks to } 3 \\
\text { months post- } \\
\text { grafting } \\
\text { NSC grafting } \\
\text { reduced: (i) } \\
\text { durations of } \\
\text { behavioral } \\
\text { seizures and } \\
\text { after } \\
\text { discharges, } \\
\text { and seizure } \\
\text { stage in the } \\
\text { kindling } \\
\text { model; } \\
\text { (ii) Frequency } \\
\text { of SRS and } \\
\text { time spent in } \\
\text { seizure activity } \\
\text { in the } \\
\text { pilocarpine } \\
\text { model }\end{array}$ & $\begin{array}{l}\text { No positive } \\
\text { effects of } \\
\text { grafts on } \\
\text { spatial } \\
\text { learning and } \\
\text { memory } \\
\text { function }\end{array}$ & $\begin{array}{l}\text { Recovery: } 57-29 \% \\
\text { of injected cells at } \\
4-8 \text { weeks post- } \\
\text { grafting in the } \\
\text { kindling model; } \\
\text { Percentage } \\
\text { survival not } \\
\text { reported for } \\
\text { pilocarpine model } \\
\text { Differentiation of } \\
\text { graft-derived cells: } \\
24 \% \text { into GABA- } \\
\text { ergic neurons; } \\
28 \% \text { into S- APC- } \\
\text { CC1+ } \\
\text { oligodendrocytes; } \\
\text { and } 8 \% \text { into } \\
\text { astrocytes. } 50 \% \text { of } \\
\text { graft-derived } \\
\text { astrocytes also } \\
\text { expressed GDNF }\end{array}$ & $\begin{array}{l}\text { Grafting } \\
\text { restored the } \\
\text { expression of } \\
\text { GDNF in host } \\
\text { astrocytes } \\
\text { Grafting did } \\
\text { not } \\
\text { ameliorate } \\
\text { the aberrant } \\
\text { mossy fiber } \\
\text { sprouting }\end{array}$ \\
\hline $\begin{array}{l}\text { Pilocarpine } \\
\text { induced SE in } \\
\text { mice }\end{array}$ & $\begin{array}{l}\text { Two-weeks } \\
\text { after SE } \\
\text { Grafts were }\end{array}$ & Not examined & $\begin{array}{l}\text { Not } \\
\text { examined }\end{array}$ & $\begin{array}{l}\text { Graft-derived } \\
\text { GABA+ neurons } \\
\text { displayed } \\
\text { electrical }\end{array}$ & $\begin{array}{l}\text { No significant } \\
\text { effect on } \\
\text { aberrant } \\
\text { mossy fiber }\end{array}$ \\
\hline
\end{tabular}




\begin{tabular}{|c|c|c|c|c|c|}
\hline $\begin{array}{l}\text { Mouse } \\
\text { embryonic stem } \\
\text { cell (mESC) } \\
\text { derived neural } \\
\text { progenitor cells } \\
\text { (NPCs) with } \\
\text { ventral forebrain } \\
\text { identities } \\
\text { Maisano et al., } \\
2012\end{array}$ & $\begin{array}{l}\text { placed into the } \\
\text { DG }\end{array}$ & & & $\begin{array}{l}\text { properties of hilar } \\
\text { interneurons and } \\
\text { received excitatory } \\
\text { synaptic } \\
\text { connections }\end{array}$ & sprouting \\
\hline $\begin{array}{l}\text { Pilocarpine } \\
\text { model of SE in } \\
\text { NOD-SCID mice } \\
\text { MGE-like } \\
\text { progenitors from } \\
\text { hESCs } \\
\text { Cunningham et } \\
\text { al., } 2014\end{array}$ & $\begin{array}{l}\text { 3 3 weeks after } \\
\text { SE } \\
\text { Grafts were } \\
\text { placed into the } \\
\text { hippocampus }\end{array}$ & $\begin{array}{l}3 \text { months after } \\
\text { grafting } \\
93 \% \text { reduction } \\
\text { in the } \\
\text { frequency of } \\
\text { seizures; } 56 \% \\
\text { of grafted } \\
\text { animals } \\
\text { displayed no } \\
\text { seizures } \\
\text { (based on } \\
\text { continuous } \\
\text { EEG for 5-10 } \\
\text { days) }\end{array}$ & $\begin{array}{l}\text { Alleviation of } \\
\text { hyperactivity } \\
\text { and } \\
\text { aggressive } \\
\text { behavior; } \\
\text { Reversal of } \\
\text { short-term } \\
\text { working } \\
\text { memory and } \\
\text { object } \\
\text { recognition } \\
\text { memory } \\
\text { dysfunction }\end{array}$ & $\begin{array}{l}\text { Survival: } 19 \% \text { of } \\
\text { injected cells. } \\
\text { Majority of graft- } \\
\text { derived cells } \\
\text { expressed GABA } \\
\text { and displayed } \\
\text { presynaptic } \\
\text { machinery for } \\
\text { releasing GABA, } \\
\text { properties for } \\
\text { inhibiting host } \\
\text { hippocampal } \\
\text { neurons and } \\
\text { postsynaptic } \\
\text { machinery for } \\
\text { receiving } \\
\text { excitatory inputs } \\
\text { from host } \\
\text { hippocampal } \\
\text { neurons }\end{array}$ & $\begin{array}{l}\text { No effect on } \\
\text { aberrant } \\
\text { mossy fiber } \\
\text { sprouting }\end{array}$ \\
\hline
\end{tabular}

